\title{
Paleosol classification: Problems and solutions
}

\author{
W.D. Nettleton, C.G. Olson*, D.A. Wysocki \\ USDA, NRCS, NSSC, 100 Centennial Mall North, Lincoln, NE 68508, USA
}

\begin{abstract}
Paleosols are soils that formed on landscapes of the geologic past. Three kinds exist — buried, exhumed, and relict. To help reconstruct paleoenvironments and for ease of comparison, we suggest a property-based classification system linked to genetic processes. We use enduring properties because alteration of paleosols following burial is common. Morphological properties such as horizonation, soil fabric, root and worm casts, and redoximorphic features are resistant to alteration and thus are valuable as criteria. Field-observable and micromorphological properties, degree of weathering, and proportion of resistant minerals are also useful as criteria for paleosol orders. Total chemical analysis provides a proxy measure for base saturation and clay mineralogy. We use proxy criteria to help classify paleosols that have changed markedly or have been lithified during or after burial. To an earlier version of the system, we add two new orders and include buried, relict, lithified, and exhumed units at the suborder level. Our system clearly separates paleosol taxon names from those of all ground soils. We use the prescript paleo- at the order level, and kryptic to designate the buried, enduric to designate the relict, lithic to designate the lithified, and emergent to designate the exhumed paleosol suborders. We use prescript modifiers to describe the physical characteristics of the paleosols and postscripts for parent material origin and the extensiveness of the paleosol landscape. We present data and classify a number of paleosols as examples of the system. Published by Elsevier Science B.V.
\end{abstract}

Keywords: Paleosol; Paleoenvironment; Property-based classification system

\section{Introduction}

Paleosols are soils that formed on landscapes of the geologic past. Some now exist in environments that differ from those in which their major features were produced. Three kinds of paleosols exist - buried, exhumed, and relict. Kinds of paleosols are defined

\footnotetext{
* Corresponding author.
} 
in terms of location relative to the land surface. Ruhe $(1965,1975)$ defined these terms as follows: "Relict paleosols are soils that formed on pre-existing landscapes, but were not buried by younger sediment. Their formation dates from the time of the original landscape and continues today. Buried paleosols also formed on pre-existing landscapes and were subsequently buried by younger sediment or rock. Exhumed soils are those that were buried but have been re-exposed on the land surface by erosion of the covering mantle.'

Previously, Nettleton et al. (1998) presented a system for classifying buried paleosols based on field observations and laboratory measurements. They use buried as defined by the Soil Survey Staff (1992a): “ . . . covered with a surface mantle of new soil material that is either $50 \mathrm{~cm}$ or more thick, or is 30 to $50 \mathrm{~cm}$ thick and has a thickness that equals at least half the total thickness of the named diagnostic horizons that are preserved in the buried soil.' Nettleton et al. (1989) define relict as any soil that is Pleistocene age or older, has remained at the land surface since its inception, and has diagnostic horizons or other features that formed in pre-Holocene environments different from today. To the last definition, we add a taxonomic requirement that a relict paleosol cannot be overlain by more than $50 \mathrm{~cm}$ of material. These definitions are used here.

As Nettleton et al. (1998) suggest, identification of the kinds of paleosols requires field investigation. Of the three types of paleosols, buried soils are the easiest to recognize. They are mantled by younger sediment. Exhumed and relict soils present greater challenges for recognition. Identification is by geomorphic and stratigraphic means. Exhumed soils are recognized with certainty only when stratigraphic continuity with a buried soil can be demonstrated. Highly contrasting soils on the same slopes can sometimes be a clue that exhumed soils are present. Relict soils occur where it is known that the pre-existing landscape is old, has remained stable, and has been subject to little erosion since soil formation began. Secondly, the presence of features or properties whose origins are clearly unrelated to present-day soil-forming conditions must be demonstrated. Soil formation has continued uninterrupted.

The properties used in the classification system of Nettleton et al. (1998) were those influenced by genetic processes, and closely paralleled Soil Taxonomy (Soil Survey Staff, 1996) as did the classification system developed by Mack et al. (1993). With both systems, proxy criteria were used to classify paleosols that had changed markedly or had been lithified during or after burial. Nettleton et al. (1998) added the prefix krypt(hidden) to all order names to clearly separate buried paleosol taxa names from those of ground soils (soils at the earth's surface). However, the system did not include relict and exhumed paleosols because these are currently classified in the systems used for ground soils. For example, U.S. Soil Taxonomy (Soil Survey Staff, 1998), the Australian Soil Classification System (Isbell, 1996), and the World Reference Base for Soil Resources (Spaargaren, 1994) include taxa for relict and exhumed paleosols as types of ground soils.

Because of the need for paleoenvironmental interpretations and for comparison between paleosols, it is desirable to extend the classification system to include all paleosols as well as lithified soils. Lithified paleosols are commonly buried paleosols although some may be exhumed. Relict paleosols are products of more than one environment; buried and exhumed paleosols may or may not be. Prior to burial, a soil 
may have been a relict paleosol exposed to more than one climate. Upon long exposure, an exhumed paleosol could be influenced by more than one environment and would meet the age requirement for a relict paleosol, but not the persistence requirement. In any case, an ideal classification system keys on the dominant environment in which the paleosol formed.

We add two new orders for paleosols and modify the classification system proposed by Nettleton et al. (1998) to include lithified paleosols and the other paleosols (buried, relict, and exhumed) at the suborder level. We replace the prefix krypt- in the order name with paleo-. We add kryptic to designate the buried, enduric to designate the relict, lithic to designate lithified, and emergent to designate the exhumed paleosols at the suborder level. The definitions are common in soil literature, geologic glossaries, and dictionaries (e.g. Soil Survey Staff, 1975; Flexner, 1987; Jackson, 1997). We use lithic at the suborder level rather than petric because petrify is understood by some (e.g. Flexner, 1987) to mean “. ... to convert into stone ...". Prescript modifiers describe the physical characteristics of the paleosol; postscript modifiers describe the parent material and the extensiveness of the paleosol. We also present data for a number of paleosols to illustrate use of the system.

\section{Proposed paleosol taxonomic system}

\subsection{Approach}

As in Nettleton et al. (1998), we use enduring properties to classify paleosols to the order level because alteration of paleosols following burial is common (Olson and Nettleton, 1998). Paleosol alteration results from several processes. Erosion and deposition truncate paleosols or bury them, either rapidly or slowly. Physical processes including erosion, mass movement, welding (Ruhe and Olson, 1980), and pedoplasmation (Flach et al., 1968) incorporate new sediment with paleosols. Chemical processes can weld younger soils to buried paleosols, and the welded profile may then affect the accumulation, dissolution, and reprecipitation of mineral material (Ruhe and Olson, 1980). Geological processes such as cementation by groundwater or low-grade metamorphism can lithify pre-existing soils. Soil properties most likely to be affected by lithification during or after burial include texture, porosity, kind and amount of clay minerals, presence or absence of soluble salts, amorphous silica, gypsum, and carbonate (Olson and Nettleton, 1998). Under most conditions, morphological properties such as horizonation, soil fabric, root and worm casts, and redoximorphic features are more resistant to alteration and thus are valuable as criteria for paleosol classification. The proportion of resistant minerals and the degree of mineral weathering are also enduring properties useful as classification criteria.

We use field-observable, laboratory, and micromorphological properties to classify paleosols at the order level. Total chemical analysis provides a proxy measure for base saturation and clay mineralogy.

Base saturation is a sensitive measure of soil weathering and is used in differentiation at several levels of Soil Taxonomy (Soil Survey Staff, 1998). We make only limited use 
Table 1

Classification key to the paleosol orders

(A) Paleosols that:

(1) Do not have andic soil properties ${ }^{\mathrm{a}}$ in subhorizons that total $30 \mathrm{~cm}$ or more within

$50 \mathrm{~cm}$ of the paleosol surface and have organic soil materials within the defined thickness ${ }^{\mathrm{a}}$,

if not lithified, or within any thickness if lithified; or

(2) If lithified, have color values $\leq 5$ and chroma $\leq 4$ when dry and a weight loss

Paleohistosols $\geq 20 \%$ when fired.

(B) Other paleosols that:

(1) Have an albic but not an argillic or kandic horizon above a spodic horizon ${ }^{\mathrm{a}}$; or

Paleospodosols

(2) Do not have an argillic or kandic horizon above a spodic horizon and have a spodic horizon of defined thickness and do not have andic soil properties in subhorizons that total $30 \mathrm{~cm}$ or more within $50 \mathrm{~cm}$ of the paleosol surface; or

(3) Have a horizon with silt-size pellets or cracked coatings on $10 \%$ or more of the sand grains as observed in thin sections, or are cemented by $\mathrm{Al}$ and organic matter with or without Fe.

(C) Other paleosols that:

(1) Have andic soil properties in subhorizons that total $30 \mathrm{~cm}$ or more within

$50 \mathrm{~cm}$ of the paleosol surface; or

(2) Have $\geq 5 \%$ volcanic glass, a NaF soil $\mathrm{pH}$ of 9.3 and lack carbonate; or

(3) If lithified, have $5 \%$ volcanic glass in the $0.02-2.0 \mathrm{~mm}$ fraction in an isotropic matrix as observed in thin section.

(D) Other paleosols that:

(1) Have an oxic horizon and no kandic horizon; ${ }^{\mathrm{a}}$ or

(2) Have a clay $(<2 \mu \mathrm{m})$ content of $40 \%$ or more (by weight) in the fine-earth fraction and a kandic horizon without clay skins that have the weatherable mineral properties of an oxic horizon; or

(3) Have a microfabric with 1:1 type (kaolin) plasma and $\geq 90 \%$ resistant minerals as skeleton grains, and lack clay skins (illuviation argillans).

(E) Other paleosols that do not have within $1 \mathrm{~m}$ of the paleosurface one or more of the following, argillic, kandic, petrocalcic or petrogypsic horizons, or duripans, but do have:

(1) Layers $25 \mathrm{~cm}$ or more thick with either: (a) slickensides close enough to intersect; or (b) wedge-shaped aggregates that have their long axes tilted $10-60^{\circ}$

from the horizontal; or (c) bowl-shaped, slickensided surfaces with a horizontal spacing of a few meters and;

(2) Unless lithified, have a weighted average of $30 \%$ or more clay in the fine-earth fraction.

(F) Other paleosols that:

(1) Have within $1 \mathrm{~m}$ of the paleosol surface one or more of the following: a petrocalcic or petrogypsic horizon, or a duripan; or

Paleoaridisols

(2) Have a vesicular horizon ${ }^{\mathrm{b}}$ at the surface of the paleosol; or

(3) Have flocculated argillans and/or flocculated arcuate papules ${ }^{\mathrm{c}}$ in the upper B horizon (Figs. 1 and 2); or

(4) Have a desert pavement ${ }^{\mathrm{b}}$ at the surface of the paleosol.

(G) Other paleosols having argillic or kandic horizons that have:

(1) Either a $10-\mathrm{cm}$ thick subhorizon with a $\mathrm{CEC}_{7}$ to clay ratio of $<0.4$, and, $<15 \%$ weatherable minerals in the very fine sand $(50-100 \mu \mathrm{m})$ or coarse silt 
Table 1 (continued)

(G) Other paleosols having argillic or kandic horizons that have:

(2) Half or more of the clay fraction made up of kaolinite; or

(3) A minimum BS sum of cations $\left(\mathrm{BS}_{8.2}\right)$ of $<18 \%$ in the upper $10 \mathrm{~cm}$ of the argillic horizon; or $<35 \%$ in the lower part of the argillic horizon; or (if lithified)

(4) A microfabric with illuvial clay features, 1:1 type (kaolin) plasma, and $\geq 85 \%$ resistant minerals in the skeleton grains.

(H) Other paleosols that have:

(1) A mollic epipedon, and (if not welded);

(2) $\geq 50 \%$ BS within $180 \mathrm{~cm}$; or (if welded);

Paleomollisols

(3) Mollic colors in $\geq 20 \mathrm{~cm}$ thick horizons; and

(4) $\geq 20 \%$ weatherable minerals in sands or silts.

(I) Other paleosols with argillic or natric horizons which have:

(1) A 10 -cm thick subhorizon with a $\mathrm{CEC}_{7}$ to clay ratio of $\geq 0.4$, and, $15 \%$

weatherable minerals in the very fine sand or coarse silt fractions; or

Paleoevolvisols

(2) Half or more of the clay fraction made up of clay mica, vermiculite, or smectite, or by a mixture of these; or

(3) A minimum $\mathrm{BS}_{8.2}$ of $18 \%$ in the upper part of the argillic horizon or $35 \%$ in the lower part of the argillic horizon; or (if lithified) have

(4) A microfabric with illuvial clay features, and $\geq 15 \%$ weatherable minerals in the skeleton grains.

(J) Other paleosols that have a cambic horizon.

Paleoinceptisols

(K) Other paleosols

Paleoaddendosols

\footnotetext{
${ }^{a}$ These features follow definitions given by the Soil Survey Staff (1992a).

${ }^{\mathrm{b}}$ Springer (1958) describes the desert pavements and vesicular crusts that develop in low-humus, loamy arid land soils.

${ }^{\mathrm{c}}$ These features are described in more detail by Nettleton et al. (1990).
}

of base saturation as a criterion because it changes with climate or soil burial. If the paleosol has no evidence of welding (Ruhe and Olson, 1980), base saturation determined by the $\mathrm{NH}_{4} \mathrm{OAc}$ method $\left(\mathrm{BS}_{7}\right)$ is used as one criterion for Paleomollisols (Table 1). In this situation, the soil or sediment above the buried paleosol does not contain carbonate, or has a base saturation value greater than that of the paleosol. Dissolution and reprecipitation of mineral material in relict and exhumed paleosols also make base saturation invalid for use as a criterion. We propose to recognize these situations by study of changes in base saturation with increasing depth. If the base saturation increases with depth, it is valid to use it as a criterion. If the base saturation decreases with depth, it is not valid to use it as a criterion. This follows from the observation that weathering is most intense at the soil surface.

A second method for determining base saturation, sum of cations $\left(\mathrm{BS}_{8.2}\right)$, is used in the key for Paleoeldisols and Paleoevolvisols (Table 1). Paleoeldisols key out first. If $\mathrm{BS}_{8.2}$ is $\leq 18 \%$ in the upper $10 \mathrm{~cm}$ of the argillic horizon, or $<35 \%$ in the lower part, the paleosol is accepted as a Paleoeldisol. The Paleoevolvisols are required to have higher base saturation values. This use is accompanied by options. Total chemical 
analysis data may be corrected for additions of salt, gypsum and carbonate and then used as proxy for base saturation (Nettleton et al., 1998). Nettleton et al. (1998) showed that weatherable mineral content correlates with $\mathrm{BS}_{8.2}$, and both are listed as optional criteria for Paleoeldisols in the key (Table 1). If the paleosol base saturation values are higher than those listed in the key, one of the other criteria will take precedence and be used to place the paleosol. From our experience with classification of ground soils, we have designed the criteria for orders to include multiple options. Our intent is to provide criteria for inclusion of both diagenetically altered and persistent paleosols in the same order, if they have enduring properties in common.

\subsection{Analytical methods}

Analytical methods are in the Soil Survey Laboratory Methods Manual (Soil Survey Staff, 1992b). We used both the $\mathrm{NH}_{4} \mathrm{OAc}$ and the sum of cations methods to measure base saturation $(\mathrm{BS})$. Base saturation $\left(\mathrm{BS}_{7}\right)$ and cation exchange values $\left(\mathrm{CEC}_{7}\right)$ by the $\mathrm{NH}_{4} \mathrm{OAc}$ method are more commonly available. $\mathrm{BS}_{7}$ may be converted to sum of cations $\left(\mathrm{BS}_{8.2}\right)$ accurately enough for paleosol classification. Where data were not available, we estimated $\mathrm{BS}_{8.2}$ using the following equation developed from the $\mathrm{B}$ and $\mathrm{C}$ horizons of soils with argillic horizons and Al saturation > 0 (Nettleton et al., 1998):

$$
\mathrm{BS}_{8.2}=0.83 \mathrm{BS}_{7}-1.5
$$

where the total number of samples is 707 and $r^{2}=0.936$. Particle size data are by pipette and sieving and follow the USDA standard for fine-earth separates: clay $(<0.002 \mathrm{~mm})$, silt $(0.050-0.002 \mathrm{~mm})$, and sand $(>0.050 \mathrm{~mm})$. The $1500 \mathrm{kPa}$ water retention is by pressure membrane apparatus. A ratio of $\leq 0.6$ for $1500 \mathrm{kPa}$ water retention to percent clay indicates an acceptable degree of complete clay dispersion (Burt, 1995). Organic carbon (OC) analysis is by the Walkley-Black method and iron content (Fe-DC) is by dithionite-citrate extraction (Soil Survey Staff, 1992b). For compacted, cemented or lithified paleosols, microfabric and total chemical analyses are used to infer such genetic processes as weathering or clay movement, or to infer the origin of parent material. For example, Nettleton et al. (1998) use the percent weatherable minerals in the sand and silt fractions as a proxy for chemical weathering and illuvial clay features (Brewer, 1976) as evidence for clay movement. We offer alternative criteria because some parent materials are not uniform in weatherable mineral content and illuviation features are not present in all soils that have other evidence of clay translocation (Nettleton et al., 1969).

\subsection{The classes (taxa) of the system}

The key to paleosol orders (Table 1) adopts some of the system proposed by Mack et al. (1993), and provides field-observable properties for the paleosol orders. It also provides micromorphological features, chemical and clay mineralogical properties as alternative criteria for paleosol orders. The combined criteria make the system more 
Table 2

Formative elements for paleosol taxa $\mathrm{a}^{\mathrm{a}}$

\begin{tabular}{|c|c|c|}
\hline Formative element & Derivation & Proposed use \\
\hline Addend & Latin addere, to put & a soil that does not fit in another class \\
\hline Eld & Middle English elde, old age & $\begin{array}{l}\text { a soil that has developed to the full extent } \\
\text { of its primary (weatherable) minerals }\end{array}$ \\
\hline Emergent & Latin emergere, to arise out of & a soil that was buried and is now exhumed \\
\hline Enduric & Latin indurare, to make lasting & a soil that has existed since inception, relict \\
\hline Evolve & Latin evolvere, to unroll & $\begin{array}{l}\text { a soil that could develop further given the } \\
\text { appropriate climate }\end{array}$ \\
\hline Krypt & Greek kryptos, hidden & $\begin{array}{l}\text { a soil that is buried by a younger soil or by } \\
\text { another material. }\end{array}$ \\
\hline Lithic & Greek Lithikos, of or relating to stone & a soil that has been hardened to rock \\
\hline
\end{tabular}

${ }^{\mathrm{a}}$ Flexner (1987). Other formative elements follow those of the Soil Survey Staff (1975).

user-friendly. The alternative field and laboratory criteria have been tested and found reliable. The laboratory data and the proxy data have also been tested (Soil Survey Staff, 1975; Burt, 1995; Nettleton et al. 1998, among others). For example, optical mineralogy and total chemical analysis provide proxy measures for base saturation and clay mineralogy. Statements about thickness refer to definitions given by the Soil Survey Staff (1998). Table 2 explains formative elements not used presently in Soil Taxonomy classes. Table 3 defines prescripts that describe the physical characteristics of paleosols, and Table 4 some of the postscripts that describe the paleosol parent material origin and its extensiveness.

Table 3

Definitions for prescript modifiers of order names for paleosols

\begin{tabular}{ll}
\hline Modifiers & Definitions \\
\hline $\begin{array}{l}\text { Accretionary } \\
\text { Buried, or kryptic }\end{array}$ & $\begin{array}{l}\text { Tending to increase by slow external addition or accumulation. } \\
\text { Covered by an alluvial, loessial, or other surface mantle of more recent depositional } \\
\text { material, usually to a depth }>50 \mathrm{~cm}^{\text {a }}\end{array}$ \\
$\begin{array}{l}\text { Complete } \\
\text { Truncated }\end{array}$ & $\begin{array}{l}\text { Possessing all necessary horizons. } \\
\text { Helded }\end{array}$ \\
$\begin{array}{l}\text { Ground soil merged through a thin cover sediment with the solum of a buried soil } \\
\text { formed in a substratum material. }\end{array}$ \\
$\begin{array}{l}\text { Carbonate-enriched } \\
\text { Unleached }\end{array}$ & $\begin{array}{l}\text { Addition of carbonate by leaching from overlying material. } \\
\text { Beached }\end{array}$ \\
Bleyed & $\begin{array}{l}\text { All carbonate and salts removed from A and B horizons. } \\
\text { Fe and Mn occur in a reduced state or have been partially or completely removed from } \\
\text { the A and B horizons. }\end{array}$ \\
Oxidized & Dominated by oxides and carbonates.
\end{tabular}

\footnotetext{
a Jackson (1997). Glossary of geology. American Geological Institute, Alexandra, VA.

${ }^{\mathrm{b}}$ Glossary Committee, 1987. Kamprath, E.J. (Chair). Glossary of Soil Science Terms. Soil Sci. Soc. Am., Madison, WI, $44 \mathrm{pp}$.

${ }^{\mathrm{c}}$ Ruhe and Olson (1980).
} 
Table 4

Example postscript modifiers used in this paper

\begin{tabular}{|c|c|}
\hline Modifiers & Definitions \\
\hline Residual & $\begin{array}{l}\text { Formed from, or resting on, consolidated rock of the same kind as that from which it was } \\
\text { formed, and in the same location. }\end{array}$ \\
\hline Alluvial & $\begin{array}{l}\text { Formed from unconsolidated detrital material, deposited during comparatively recent geologic } \\
\text { time by a stream or other body of running water. }\end{array}$ \\
\hline Colluvial & $\begin{array}{l}\text { Formed from loose, heterogeneous material deposited by rainwash, sheetwash or slow } \\
\text { downslope creep, usually collecting at the base of slopes. }\end{array}$ \\
\hline Eolian & Formed from wind-blown deposits of silt, sand, granules, and pebbles. ${ }^{\text {a }}$ \\
\hline Pyroclastic & 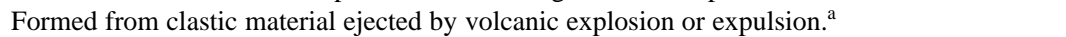 \\
\hline Extensive & Distribution and extent $>4050$ ha $(10,000$ acres $) .^{\mathrm{b}}$ \\
\hline Inextensive & Distribution and extent $<4050$ ha $(10,000$ acres $){ }^{\text {b }}$ \\
\hline
\end{tabular}

${ }^{\mathrm{a}}$ Jackson (1997).

${ }^{\mathrm{b}}$ Soil Survey Staff (1996).

\subsubsection{Paleohistosols}

Paleohistosols are important both for economic and paleoenvironmental reasons. They include consolidated and unconsolidated deposits. They are useful for interpreting landscape evolution and for sequestering carbon. They mark the landscape positions of former wetness (Soil Survey Staff, 1975). Commonly, they have plant remains and pollen grains that are useful for understanding the ancient flora (Baker, 1983; Davis, 1983; Watts, 1983). Some Paleohistosols can be dated radiometrically and provide an absolute datum for geochronologic interpretation in a stratigraphic section. Color, composition, and weight loss upon firing provide alternative methods for their classification. Current interests in carbon sequestration also are stimuli for mapping and quantifying the Paleohistosols.

\subsubsection{Paleospodosols}

Paleospodosols may have formed in a broad range of soil temperatures. In the United States, they occur in soil temperature regimes (Soil Survey Staff, 1998) ranging from thermic to frigid (Rourke et al., 1988). Rourke et al. (1988) found that the morphology of warm Spodosols differs from that of cold Spodosols. Some inferences about paleotemperature also may be possible for the Paleospodosols. Like present-day Spodosols, Paleospodosols may represent a strong leaching environment in which $\mathrm{Fe}$ - and Al-organic matter complexes accumulate in illuvial horizons (McKeague et al., 1983). Like the present-day Spodosols, they may have been associated mostly with conifers and deciduous forests, shrubs, and mosses. The horizon sequence $\mathrm{E}$ over a Bh or Bs and the micromorphology are specific for Spodosols (Soil Survey Staff, 1998) and for Paleospodosols (Nettleton et al., 1998). However, it is important to follow the key because the amorphous component in Paleospodosols may be similar to that in Paleoandisols (Nettleton et al., 1998).

\subsubsection{Paleoandisols}

Paleoandisols follow Paleospodosols in the key because they form under similar vegetative and climatic conditions and the amorphous components of the two are 
similar. Paleoandisols differ in having formed almost exclusively in volcanic ejecta, or in mixtures of tephra and other parent materials. They do not have E or Bh horizons; instead, OC decreases regularly with depth. Incomplete (eroded) Paleospodosols resemble Paleoandisols, so we key them out first. Paleohistisols may have similar color but are keyed out before the Paleoandisols because of their higher OC content.

\subsubsection{Paleooxisols}

Paleooxisols are of importance to paleopedology because they represent an extreme soil-weathering environment. Oxisols lack weatherable minerals in the silt and sand fractions, except for grains entirely coated by sesquioxides (Soil Survey Staff, 1996; Alexander and Cady, 1962). They may have an organic-matter-rich surface horizon, but differ from the Paleohistisols, Paleospodosols, and Paleoandisols in having either an oxic or a kandic horizon. Oxic and kandic horizons are both chemically and mineralogically strongly weathered horizons (Soil Survey Staff, 1998). Both differ in their textural relationships with their overlying A or E horizons. Kandic horizons, like argillic horizons, contain more clay than the overlying horizons. Because of the possibility that the A or E horizon may not be preserved in the paleosol, we require that the kandic horizons in Paleooxisols do not have clay skins. Strongly weathered ancient soils that do contain clay skins are included with the Paleoeldisols that key out later in the classification. Oxic horizons are sandy loam or finer in texture and contain amounts of clay similar to the overlying horizons (Soil Survey Staff, 1998).

Soil sediment is defined by Bronger and Catt (1989) as redeposited soil material. Soil sediment derived from strongly weathered soils, if not finely stratified, may meet the criteria for Paleooxisols. However, detailed study of the paleolandscape can eliminate most of these from consideration as Paleooxisols. For those not eliminated, many of the paleoclimatic inferences made will be the same as those made for other typical Paleooxisols.

Oxisols can be recognized even in rock because of their extensive chemical alteration (Retallack and German-Heins, 1995). An order of Paleooxisols is justified because such soils suggest formation in perhumid tropical or subtropical environments on geomorphic surfaces of great age (Soil Survey Staff, 1975). Oxisols currently exist under both rain forest and savannah (Van Wambeke et al., 1983), so recognition of a Paleooxisol does not, of itself, identify the vegetation during paleosol formation.

\subsubsection{Paleovertisols}

Paleovertisols provide evidence for a seasonally wet-dry environment. They have a weighted average clay content $>30 \%$. They do not have the A to B horizon clay increase required of argillic horizons. Their microfabrics have stress features (Mermut et al., 1988). Blokhuis (1993) reported skew and joint skew planes and gilgai microrelief in several Sudanese soils. We do not use microfabric features as criteria because they are not unique to Paleovertisols (Nettleton and Sleeman, 1985).

Commonly, bowl-shaped slickensided surfaces (Williams and Touchet, 1988) and gilgai (Hallsworth, 1968) occur across a scale of about a meter. The bowl-shaped morphology may differentiate lithified paleosols from stressed rocks that have the 
microfabrics of Paleovertisols but are unrelated to paleosols. Gilgai features, commonly found at the soil surface, are less likely to survive erosion and burial.

\subsubsection{Paleoaridisols}

Paleoaridisols include most of the more strongly developed ancient Aridisols. Some of the criteria for recognition of present-day Aridisols (Soil Survey Staff, 1998) are not reliable for paleosols. For example, the climates of Paleoaridisols are not now measurable (Mack et al., 1993) and the contents of salt, gypsum and carbonate can change (Olson and Nettleton, 1998). Because of these predicaments, recognition of some ancient arid soils using our key is not possible. By keying on their more enduring properties, some Paleoaridisols with less well-developed calcic, gypsic or silica-cemented horizons clearly key out after the Paleoaridisols (Table 1). Furthermore, classification of duripans and petrocalcic horizons may be a problem because these features occur in present-day xeric and ustic as well as aridic soil moisture regimes, whereas Aridisols are recognized only in the aridic regimes (Soil Survey Staff, 1998). However, we estimate that the inclusion of ancient soils of more humid environments is slight because about $85 \%$ of the U.S. soil series with petrocalcic or petrogypsic horizons or duripans is in arid and semi-arid environments today (Soil Survey Staff, 1990).

We include vesicular desert soil crusts (Jackson, 1957; Springer, 1958) and desertvarnished rock pavements as criteria because they are common features of present-day Aridisols (Nettleton and Peterson, 1983). They may be preserved most often in ancient soils buried by eolian sediment. The vesicles can form or reform after a single heavy wetting in a desert environment and an ancient desert pavement would lose its patina if exposed to a less arid environment (Nettleton and Peterson, 1983). Although some workers (Nikiforoff, 1937; Barshad, 1955, p. 40) suggest that clay translocation does not occur in desert soils, it creates unique forms in some Aridisols. Nettleton et al. (1990) described some of these as flocculated argillans (Fig. 1A and B) and flocculated arcuate papules (Fig. 2A and B).

Although the proposed criteria do not enable all ancient arid soils to be recognized, and may even select a few other kinds of soils, we propose a Paleoaridisol order because the paleoenvironments of those we can identify contrast strongly with those of other soils.

\subsubsection{Paleoeldisols}

Paleoeldisols provide valuable insight into paleoenvironments because they are defined by criteria designed to select ancient Ultisols. Ultisols are soils whose weathering stage is between that of Alfisols and Oxisols (Soil Survey Staff, 1998). Most present-day Ultisols, and presumably ancient ones, formed in forests in soil temperature regimes warmer than frigid or cryic (Miller, 1983). Some Ultisols in the tropics formed in savannahs. All present-day Ultisols have low base saturation and argillic horizons. Both Ultisols and, presumably, Paleoeldisols formed under alternating periods of high evapotranspiration and low rainfall followed by periods of higher precipitation and through leaching (Miller, 1983). Paleoeldisols are less weathered than Paleooxisols and differ further in having argillic horizons or kandic horizons with clay skins. Translocated clay and weatherable minerals both may be observed in thin sections of Paleoeldisols, 

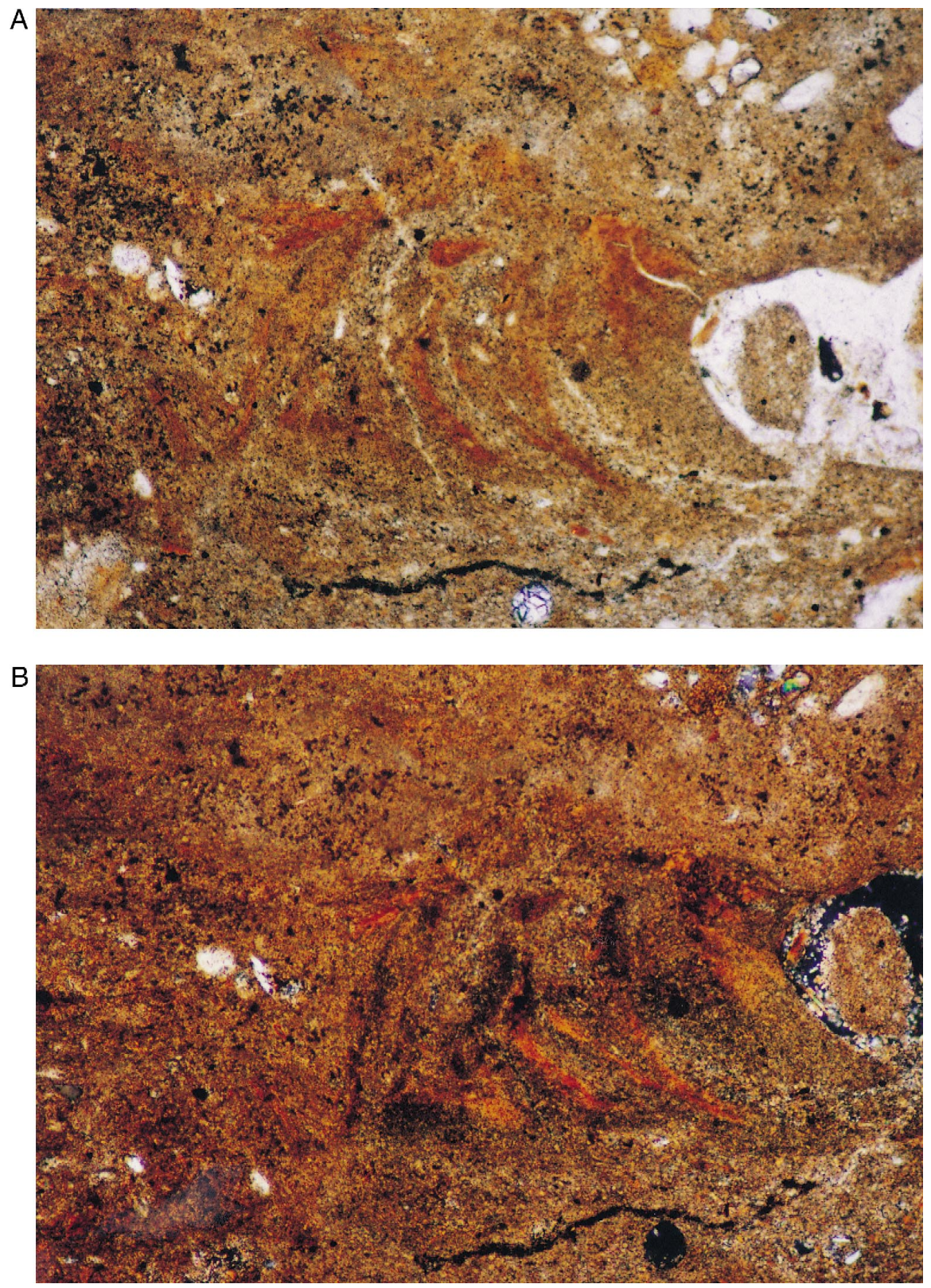

Fig. 1. Photomicrograph of the AB horizon from the Ligurta pedon (S76AZ 27-2), a Typic Haplargid from Yuma County, AZ. (A) In plain light showing illuviation argillans associated with a channel. The argillans have arcuate form and diffuse boundaries. (B) In crossed polarized light showing moderate to weak orientation. Extinction brushes are very broad. Frame width $=2 \mathrm{~mm}$. 

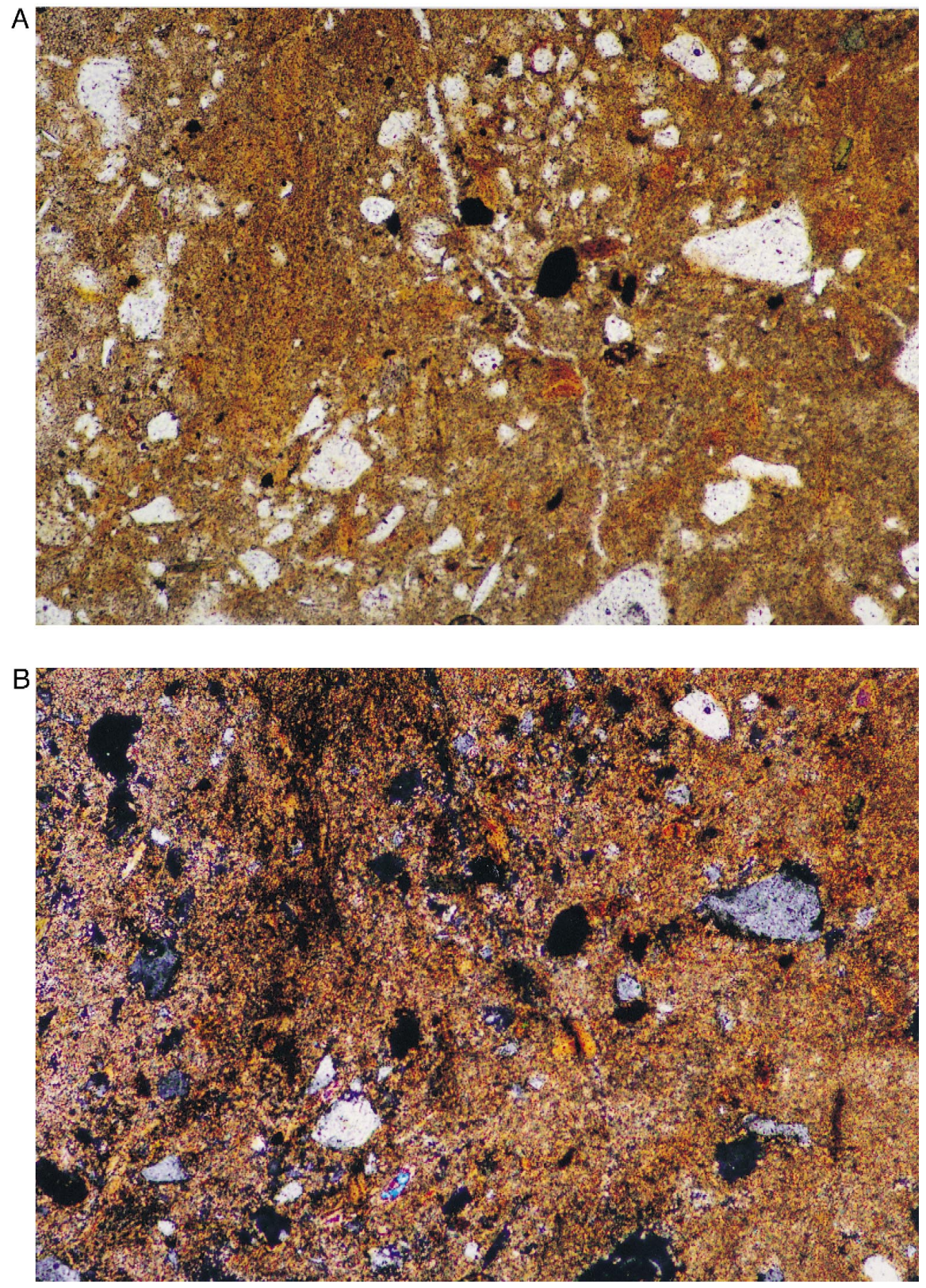

Fig. 2. Photomicrograph of the AB horizon from the Ligurta pedon (S76AZ 27-2), a Typic Haplargid from Yuma County, AZ. (A) In plain light showing a large area of plasma (centered) with diffuse boundaries and scattered smaller arcuate areas. (B) In crossed polarized light showing that, except for the smaller areas, the plasma has very broad extinction brushes. Frame width $=2 \mathrm{~mm}$. 
even if lithified, thus making these efficient classification criteria. Because of the possibility of erosion, a clay increase is not required of Paleoeldisols. Instead, clay skins are necessary, but as a result Paleoeldisols may include some Oxisols because a few Oxisols have clay skins in their lower horizons (Nettleton et al., 1987). The $\mathrm{CEC}_{7}$-to-clay ratio and the weatherable mineral content criteria for Paleoeldisols provide alternative criteria to the $\mathrm{BS}_{8.2}$ used for Ultisols (Soil Survey Staff, 1998). These are provided in case the Paleoeldisols are cemented by the accumulation of carbonate from a younger, overlying material. Where no cementation has occurred, the $\mathrm{BS}_{8.2}$ criteria are provided because burial or exposure to further weathering is not likely to decrease the bases, i.e. will not convert a Paleoevolvisol into a Paleoeldisol.

\subsubsection{Paleomollisols}

Paleomollisols may not include all ancient Mollisols because of oxidation and other causes of loss of OC upon burial. To provide for possible compaction caused by burial, we reduced the thickness criterion for the mollic epipedon to $20 \mathrm{~cm}$. We use mineralogical criteria as proxy for the base saturation criterion used for present-day Mollisols. Most present-day Mollisols, and presumably Paleomollisols, formed in grasslands in mesic temperature regimes and in soil moisture regimes other than aridic (Fenton, 1983). These environmental interpretations make it important to recognize Paleomollisols.

\subsubsection{Paleoevolvisols}

Paleoevolvisols are the less-weathered ancient soils that lack mollic epipedons and have argillic or natric horizons. The order is designed to include ancient Alfisols. Criteria for their differentiation include clay mineralogy, sand or silt mineralogy, microfabric features and base saturation. Any base saturation value greater than a minimum value is acceptable (Table 1). This criterion is important only when the ancient soil has not undergone welding or modification following its formation. Paleosols without mollic epipedons or oxic horizons and with lower base saturation values and clay skins are Paleoeldisols and key out before the Paleoevolvisols. Most present-day Alfisols, and presumably Paleoevolvisols, formed under mixed hardwood forests in a humid, continental-type climate (Rust, 1983).

\subsubsection{Paleoinceptisols}

Paleoinceptisols are paleosols that have a cambic horizon, as defined by the Soil Survey Staff (1998). Foss et al. (1983) state that present-day Inceptisols have formed in a variety of climates in one of two situations: (1) in geologically young sediments or landscapes; or (2) in areas where environmental conditions inhibit soil-forming processes. Most Paleoinceptisols are likely to occur as either buried or exhumed paleosols. This is because most relict ground soils are of Pleistocene or older age and have developed diagnostic horizons that key out before the Paleoinceptisols. However, there are environments that may produce relict Paleoinceptisols, e.g. a cryic or frigid soil temperature environment, or a perhumid moisture regime (Soil Survey Staff, 1998). Both environments inhibit soil development.

\subsubsection{Paleoaddendosols}

Paleoaddendosols are all other paleosols, i.e. those lacking any diagnostic criteria of the foregoing orders. As Grossman (1983) reported for Entisols, the challenge is 
deciding whether a layer is soil or not. Defining paleosols as we have means that the Paleoaddendosols include mostly sands and coarser soils. Even during early Holocene, fine-textured soils have had time to develop one or more diagnostic horizons. Coarser soils, by definition, do not have cambic horizons (Soil Survey Staff, 1998). They are most likely to be recognized as Paleoaddendosols if they show some accumulation of OC, but not enough for a mollic epipedon. If A horizons of Paleoaddendosols are lacking, it is not likely that the material will be recognized as a paleosol.

\section{Application of the system}

The following paleosols are classified using the key to orders given in Table 1. Suborders are selected in the sequence lithic, kryptic, enduric and emergent using the definitions from Table 2. This sequence allows lithified soils to be classified first, whether they are buried, relict, or exhumed. This is because lithified soils are uniquely characteristic and should be a separate suborder. Prescript and postscript modifiers of the suborders are less formal (Tables 3 and 4). We capitalize the first letter of prescript modifiers but not of postscript ones.

\subsection{The Rainbow Beach Paleosol}

This paleosol (Table 5) occurs near the base of brownish-yellow dunes of the Queensland Coast $175 \mathrm{~km}$ north of Brisbane, Australia (Ward et al., 1979). The dunes occupy approximately 24,000 ha. It developed in eolian sands overlying a beach deposit that is considered to be several hundred thousand years old. There is an unconformity between the beach deposit and the overlying eolian sands. The present environment is subtropical. Where described, the paleosol is in the lower half of a $13-\mathrm{m}$ section. There

Table 5

The Rainbow Beach Paleosol

Location: about $4 \mathrm{~km}$ NW of Double Island Point in Southeast Queensland, Australia. The data and description are modified from a soft sandstone paleosol of Ward et al. (1979).

Classification: Complete, Gleyed, Kryptic Paleospodosol, eolian, extensive.

\begin{tabular}{llllll}
\hline Horizon $^{\mathrm{a}}$ & Depth $(\mathrm{cm})$ & Munsell color moist & Field texture $^{\mathrm{b}}$ & Consistence moist $^{\mathrm{b}}$ & Boundary $^{\mathrm{b}}$ \\
\hline $\mathrm{Ab}$ & $585-625$ & 10YR 2/1 & ls & fr & $\mathrm{d}$ \\
$\mathrm{Eb}$ & $625-695$ & 10YR 9/1 & $\mathrm{s}$ & lo & $\mathrm{d}$ \\
$\mathrm{Bb}$ & $695-800$ & 10YR 4/1 & $\mathrm{s}$ & $\mathrm{Nd}^{\mathrm{c}}$ & $\mathrm{c}$ \\
$\mathrm{Bhsb}$ & $800-815$ & 10YR 2/1 & $\mathrm{s}$ & vfi & $\mathrm{d}$ \\
$\mathrm{Cb}^{\mathrm{d}}$ & $815-1095$ & 10YR 5/1 and 6/1 & $\mathrm{s}$ & efr & \\
\hline
\end{tabular}

${ }^{a}$ Horizon nomenclature are from Soil Survey Staff (1998).

${ }^{b}$ Abbreviations for texture, consistency and boundary are from Soil Survey Staff (1951).

${ }^{\mathrm{c}} \mathrm{Nd}=$ not determined.

${ }^{\mathrm{d}}$ Three samples of the underlying sand rock have $89-92 \%$ sand, $4.33-5.48 \%$ organic matter, $0.34-0.36 \%$ $\mathrm{Al}, 0.02-0.04 \% \mathrm{Fe}$, and a C/Al ratio of 28.1 to 31.4 (Ward et al., 1979). 
are organic coatings on sand grains in the upper part of the B horizon and the Bhsb horizon below is a very firm soft sandstone as a result of cementation by organic-Al complexes (Ward et al., 1979). These are good diagnostic criteria for the recognition of spodic material (Buurman, 1993). The sand fraction throughout the paleosol is nearly pure quartz. The paleosol has a chroma of 2 or less, and Fe content is much less than $\mathrm{Al}$ content, suggesting formation in a wet environment. The Rainbow Beach Paleosol is a Complete, Gleyed, Kryptic Paleospodosol, eolian, extensive.

\subsection{The Molokai Paleosol}

This paleosol (Soil Survey Staff, 1976, pp. 182-183) formed in olivine basalt (Table 6) on an early Pleistocene surface of Oahu Island, Hawaii (Ruhe et al., 1965). Present precipitation at this site averages $<55 \mathrm{~cm}$, less than is common for Oxisols. Kaolinite increases with depth and gibbsite occurs only in the upper horizons. Since halloysite was not determined for this paleosol, some of the kaolinite may be halloysite, particularly where gibbsite is present. Both gibbsite and halloysite have been found to co-exist in ground soils of drier areas on the Big Island of Hawaii (Chadwick et al., 1994). The kaolinite may have formed during an earlier phase of soil development when precipitation was greater. Ruhe (1964) calculated paleo-isohyetal patterns for low sea stands using mathematical relationships between the present isohyetal pattern of Oahu and its present topographic and orographic surface. This showed that precipitation at the site during the early Pleistocene may have been $100 \%$ more than at present. Geobotanical evidence shows that past sea levels stood both higher and lower than present (Gavenda, 1992). Samples from this paleosol do not disperse well in dilute sodium hexametaphosphate solution. Assuming that the paleosol is a clayey soil, its effective cation exchange capacity is in the range for Paleooxisols $(<12 \mathrm{cmol} / \mathrm{kg}$ of clay; Soil Survey Staff, 1998). The Molokai Paleosol is a Complete, Oxidized, Leached, Enduric Paleooxisol, residual, extensive.

Table 6

The Molokai Paleosol, Honolulu County, Oahu Island, HI

About $0.6 \mathrm{~km}$ from Highway 83 on road to Waikele Naval Ordnance Depot. Data are from Soil Survey Staff (1976), pp. 183-184.

Classification: Complete, Oxidized, Leached, Enduric Paleooxisol, residual, extensive.

\begin{tabular}{|c|c|c|c|c|c|c|}
\hline Horizon & $\begin{array}{l}\text { Depth } \\
(\mathrm{cm})\end{array}$ & $\begin{array}{l}\mathrm{KK}^{\mathrm{a}} \\
(\mathrm{g} / \mathrm{kg})\end{array}$ & $\begin{array}{l}\mathrm{GI}^{\mathrm{a}} \\
(\mathrm{g} / \mathrm{kg})\end{array}$ & $\begin{array}{l}\mathrm{BS}_{8.2}^{\mathrm{a}} \\
(\%)\end{array}$ & $\begin{array}{l}\mathrm{OC}^{\mathrm{a}} \\
(\mathrm{g} / \mathrm{kg})\end{array}$ & $\begin{array}{l}\text { Soil description }{ }^{\mathrm{b}}, \\
\text { color and other features }\end{array}$ \\
\hline Ap & $0-28$ & 240 & 130 & 50 & 0.098 & 2.5 YR sicl, $1 \mathrm{fgr}, \mathrm{cw}$ \\
\hline Bo1 & $28-75$ & 470 & 100 & 38 & 0.049 & 2.5 YR sicl, 1csbk, cw \\
\hline Bo2 & $75-103$ & 520 & 20 & 43 & 0.025 & $2.5 \mathrm{YR}$ sicl, $1 \mathrm{msbk}, \mathrm{cw}$ \\
\hline Bo3 & $103-133$ & 400 & - & 48 & 0.029 & 2.5 YR sicl, 3vfsbk, cs \\
\hline Bo4 & $133-173$ & 500 & - & 52 & 0.017 & 2.5 YR sicl, 3vfsbk \\
\hline
\end{tabular}

${ }^{\mathrm{a}} \mathrm{KK}=$ kaolinite; $\mathrm{GI}=$ gibbsite; $\mathrm{BS}_{8.2}=$ base saturation; OC = organic carbon. See Soil Survey Staff (1992b) for methods of analysis.

${ }^{\mathrm{b}}$ See Table 5 and Soil Survey Staff (1951) for additional abbreviations. Munsell color is moist. 


\subsection{The Honouliuli Paleosol}

This also occurs on Oahu Island, Hawaii (Soil Survey Staff, 1976, pp. 192-193; 196-197). It has some properties of an Oxisol, but the cation exchange capacity ( $>12$ $\mathrm{cmol} / \mathrm{kg}$ of clay) is too high (Table 7$)$, and mean annual precipitation $(55 \mathrm{~cm})$ is too low. It formed on a Middle Pleistocene coral platform in subaerially derived basalt detrital alluvium (Ruhe et al., 1965). Total Ca and total $\mathrm{Mg}$ data (Table 5) suggest that if these elements occur in the silt or very fine sand fractions as anorthite and olivine, respectively, the soil has $>10 \%$ weatherable minerals in the sand and silt fractions. This is likely because Hawaiian basalts contain no quartz or other resistant minerals (as defined by Soil Survey Staff, 1975), so that all grains produced from the basalt are weatherable. Kaolinite dominates the clay fraction and small amounts of gibbsite occur throughout the profile. Like the Molokai Paleosol, the kaolinite in this profile may have formed during an earlier, wetter climate (Ruhe, 1964); however, some reported kaolinite may be halloysite. The paleosol has slickensides and field textures remain uniform with depth. The paleosol is saturated with bases which may have accumulated with the onset of drier conditions. It is classified as a Complete, Oxidized, Unleached, Enduric Paleovertisol, alluvial, inextensive.

\subsection{The Beattie Paleosol}

This example (Table 8) occurs in Richardson County, NE in the lower Permian, Upper Eskridge Formation. It has many of the characteristics of a Vertisol. Its ABssb horizon is light gray to light olive gray (5Y 7/2-6/2), calcareous, and can be broken in the hands only with difficulty. The Bssb horizon has strong, medium, blocky structure in the upper part. The nearly pure plasma segregations and slickensides are evidence that clay is the dominant size fraction. The lower part of the Bssb horizon is weak red (10YR 5/3-5/4), grading to reddish gray (10R 6/1) with depth. The multiple 1-2 m-wide bow-shaped slickensides that occur within the lower part of the Bssb horizon are

\section{Table 7}

The Honouliuli Paleosol, Honolulu County, Oahu Island, HI

Ewa Sugar Plantation, field number 53, 36 m north of Ewa School. Data are from Soil Survey Staff (1976), pp. 196-197.

Classification: Complete, Oxidized, Unleached, Enduric Paleovertisol, alluvial, inextensive.

\begin{tabular}{lcllllll}
\hline Horizon & $\begin{array}{l}\text { Depth } \\
(\mathrm{cm})\end{array}$ & $\begin{array}{l}\mathrm{Total} \mathrm{Ca}^{\mathrm{a}} \\
(\mathrm{g} / \mathrm{kg})\end{array}$ & $\begin{array}{l}\mathrm{Total} \mathrm{Mg}^{\mathrm{a}} \\
(\mathrm{g} / \mathrm{kg})\end{array}$ & $\begin{array}{l}\mathrm{CEC}_{7} \\
(\mathrm{cmol} / \mathrm{kg})\end{array}$ & $\begin{array}{l}\mathrm{BS}_{7} \\
(\%)\end{array}$ & $\begin{array}{l}\mathrm{OC} \\
(\mathrm{g} / \mathrm{kg})\end{array}$ & $\begin{array}{l}\text { Soil description }^{\mathrm{b}}, \\
\text { color and other features }\end{array}$ \\
\hline Ap & $0-38$ & 0.011 & 0.022 & 27.0 & 98 & 0.074 & 5YR 3/2 clay 2f-mg \\
Boss1 & $38-65$ & 0.011 & 0.014 & 24.9 & 104 & 0.021 & 5YR 3/2 clay 2csbk ss \\
Boss2 & $65-90$ & 0.007 & 0.019 & 25.5 & 120 & 0.020 & 5YR 3/2 clay 1msbk ss \\
Boss3 & $90-120$ & 0.097 & 0.150 & 25.3 & 121 & 0.008 & 5YR 3/3 clay 2f-msbk ss \\
Boss4 & $120-170$ & 0.141 & 0.142 & 24.6 & 129 & 0.002 & 5YR 3/2 clay 2f-msbk ss \\
\hline
\end{tabular}

\footnotetext{
${ }^{\mathrm{a}}$ Total $\mathrm{Ca}$ and $\mathrm{Mg}$ were determined in the leachate from sodium carbonate fusion. $\mathrm{Ca}$ was determined volumetrically with permanganate and $\mathrm{Mg}$ gravimetrically as phosphate.

${ }^{\mathrm{b}}$ See Table 5 and Soil Survey Staff (1951) for additional abbreviations. Munsell colors are moist.
} 
Table 8

The Beattie Paleosol, Richardson County, NE

About $3 \mathrm{~km}$ ENE of Humbolt (W1/2 NW1/4 SW1/4 SW1/4 Sec. 36 T. 3N., R. 13E.) in a borrow pit excavation. The description is modified from pedon 5, locality 1, Joeckel (1991). The lower horizons have a skel-masepic plasmic fabric.

Classification: Complete, Brecciated, Gleyed, Unleached, Kryptic Paleovertisol, alluvial, extensive.

\begin{tabular}{|c|c|c|}
\hline Horizon & Depth $(\mathrm{cm})$ & Description \\
\hline Abssb & $0-145$ & $\begin{array}{l}\text { light gray to light olive gray (5Y 7/2-6/2) massive, calcareous mudstone with } \\
\text { diffuse black } 5 \text { Y } 2.5 / 1 \text { stains on joint faces; very dark gray }(5 \mathrm{YR} 3 / 1) \\
\text { carbonate nodules; many small, poorly developed slickensides; } \\
\text { a few, wavy, structureless, carbonate-cemented sheets; clear smooth boundary }\end{array}$ \\
\hline Bssb & $145-300$ & $\begin{array}{l}\text { weak red (10YR 5/3-5/4) strongly calcareous, massive, brecciated mudstone, } \\
\text { with pale red (10R 6/3) aggregates and weak red vein-like fillings } \\
\text { between them; many wavy, carbonate-cemented sheets; gradual smooth } \\
\text { lower boundary }\end{array}$ \\
\hline Bcssb & $300-320$ & $\begin{array}{l}\text { reddish gray }(10 \mathrm{R} 6 / 1) \text { strongly calcareous, massive, brecciated mudstone with } \\
\text { reddish gray aggregates and pale red }(10 \mathrm{R} 6 / 2) \text {, vein-like mudstone fillings } \\
\text { between them; gradual smooth lower boundary }\end{array}$ \\
\hline $\mathrm{Crb}$ & $320+$ & $\begin{array}{l}\text { light gray (10YR 6/1) strongly calcareous, poorly fissile mudshale with irregular, } \\
\text { diffuse, gray (10YR 6/1); grades into plant-bearing shales below }\end{array}$ \\
\hline
\end{tabular}

striking. The Bssb horizon is also calcareous and breaks to angular blocks. Joeckel (1991) interpreted the wavy carbonate-rich sheets as post-Permian features that follow slickenside surfaces. Other slickenside surfaces in the paleosol intersect at acute angles. With depth, the horizon grades to a light gray (10YR 6/1), strongly calcareous, massive mud shale. The clay mineral suite is dominated by illite, possibly because of diagenesis (Joeckel, 1991). The paleosol is classified as a Complete, Brecciated, Gleyed, Unleached, Kryptic Paleovertisol, alluvial, extensive.

\subsection{The Eskridge Paleosol}

This paleosol (Table 9) also occurs in Richardson County, NE, in the Lower Permian Upper Eskridge Formation (Joeckel, 1991). The morphology suggests that the Bwb horizon was gleyed by a late- or post-pedogenic perched water table. The overlying rock is a grayish, weakly fissile, mud shale. Ped interiors have reddish hues (10R). The plasmic fabric of the Bwb is lattisepic. Although this paleosol has slickensides and the clay content required of a Paleovertisol, it also has a petrocalcic horizon. We designed the classification system to place soils with petrocalcic horizons in the Paleoaridisols. Soils with high shrink-swell properties occur in a range of soil moisture regimes, whereas petrocalcic horizons indicate limited moisture. We gave moisture condition proxies priority at the order level. The color pattern within the petrocalcic horizon suggests that the drainage altered from well to poorly drained after the horizon formed. Since our intent is to classify paleosols as they were when first formed, the prescript oxidized is attached (Table 3). It is likely that both the vertic and the aquic properties developed after the Paleoaridisol formed. The Eskridge paleosol is an example of a Complete, Brecciated, Gleyed, Unleached, Lithic Paleoaridisol, alluvial, extensive. 
Table 9

The Eskridge Paleosol, Richardson County, NE

About 4 km ESE of Humbolt, (SW1/4 NW1/4 SW1/4 SW1/4 Sec. 8, T. 12N, R. 14E) in a large excavation. Modified from paleosol P4, locality 2 (Joeckel, 1991).

Classification: Complete, Brecciated, Gleyed, Unleached, Lithic Paleoaridisol, alluvial, extensive.

\begin{tabular}{|c|c|c|}
\hline Horizon & Depth $(\mathrm{cm})$ & Description \\
\hline $\mathrm{Abb}$ & $0-28$ & $\begin{array}{l}\text { light gray (5Y } 7 / 1-6 / 1) \text {, massive, strongly calcareous mudstone with few, } \\
\text { medium subvertical, weak red }(10 \mathrm{R} 5 / 2) \text { vermicular mottles, presumably } \\
\text { after roots; few indistinct carbonate nodules; smooth lower boundary }\end{array}$ \\
\hline Bwb & $28-40$ & $\begin{array}{l}\text { spheroidally weathering, bluish gray ( } 5 \mathrm{~B} 5 / 1) \text {, noncalcareous to very weakly } \\
\text { calcareous, brecciated mudstone (interpreted as fine to medium subangular } \\
\text { blocky peds); small light greenish gray }(5 \mathrm{GY} 7 / 1) \text { patches } \\
\text { with abrupt margins; abundant shiny to irridescent, reddish } \\
\text { slickensides; scattered, very small weak red }(10 \mathrm{R} 5 / 3) \text {, calcareous } \\
\text { patches with sharp margins; abrupt lower boundary }\end{array}$ \\
\hline $\mathrm{Bkmb}$ & $40-65$ & $\begin{array}{l}\text { light gray }(10 \mathrm{YR} 7 / 1) \text { weathering to very pale brown }(10 \mathrm{YR} 8 / 3-7 / 3) \text {, } \\
\text { indurated, massive micrite; many small veins filled with reddish } \\
\text { gray }(10 \mathrm{YR} 5 / 1) \text { mudstone; abrupt wavy lower boundary }\end{array}$ \\
\hline
\end{tabular}

\subsection{The Alamogordo Paleosol}

This example (Table 10) occurs near the town of Alamogordo and White Sands National Monument in Otero County, NM, northeast of Pleistocene Lake Otero (Nettleton et al., 1982). The soil formed during one of the Pleistocene pluvial periods and includes a petrocalcic horizon. By the beginning of the Holocene, a much larger Pleistocene Lake Otero had been reduced to the small, contemporary Lake Lucero. Gypsum blown from the drying lake bed blanketed the paleosol with a 30-cm deposit. The ground soil developed at the site is welded to the paleosol. Because the welded ground soil has a gypsic horizon over a petrocalcic horizon at $<1 \mathrm{~m}$ depth, it classifies in the U.S. as a Petrocalcic Petrogypsid (Soil Survey Staff, 1998). As a paleosol, it is classified as a Complete, Oxidized, Unleached, Enduric Paleoaridisol, eolian/alluvial, inextensive.

\subsection{The Jeffuiew Paleosol}

Occurring in Jefferson County, OR, this is a third example of a Paleoaridisol (Table 11). It is a relict paleosol because it is overlain by $<50 \mathrm{~cm}$ of loess. It is in the late Pleistocene or older loess belt mapped by Busacca et al. (1992). The ground soil is formed in loess and volcanic ash over pedisediment and residuum from basalt. At some sites, the basalt is buried to depths greater than $1 \mathrm{~m}$. The duripan has silica laminae with embedded durinodes (Fig. 3A and B). Well-oriented clay is interlaminated with the silica. Illuviation argillans are also common on the faces of peds and in pores and channels in the $2 \mathrm{Bt}$ horizon above the duripan. The paleosol has an argillic horizon and a duripan (Flach et al., 1992), so it is classified as a Complete, Oxidized, Unleached, Enduric Paleoaridisol, eolian/pyroclastic, extensive. 
Table 10

The Alamogordo Paleosol, Otero County, NM $\left(32^{\circ} 54^{\prime} 17^{\prime \prime} \mathrm{N}, 105^{\circ} 59^{\prime} 44^{\prime \prime} \mathrm{W}\right)$

Data are from Nettleton et al. (1982).

Classification: Complete, Oxidized, Unleached, Enduric Paleoaridisol, eolian/alluvial, inextensive.

\begin{tabular}{|c|c|c|c|c|c|c|c|c|c|c|c|c|}
\hline \multirow[t]{2}{*}{ Horizon } & \multirow{2}{*}{$\begin{array}{l}\text { Depth } \\
(\mathrm{cm})\end{array}$} & \multirow{2}{*}{$\begin{array}{l}\text { Clay } \\
(\%)\end{array}$} & \multirow{2}{*}{$\begin{array}{l}\text { Silt } \\
(\%)\end{array}$} & \multirow{2}{*}{$\begin{array}{l}\text { Sand } \\
(\%)\end{array}$} & \multirow{2}{*}{$\begin{array}{l}\mathrm{OC} \\
(\mathrm{g} / \mathrm{kg})\end{array}$} & \multirow{2}{*}{$\begin{array}{l}\text { Soil description }{ }^{\mathrm{a}} \text {, } \\
\text { color and other features }\end{array}$} & \multirow{2}{*}{$\begin{array}{l}\mathrm{CEC}_{7} \\
(\mathrm{cmol} / \mathrm{kg})\end{array}$} & \multirow{2}{*}{$\begin{array}{l}\text { Whole soil } \\
>2 \mathrm{~mm}(\%)\end{array}$} & \multicolumn{2}{|c|}{ Calcium carbonate } & \multirow{2}{*}{$\begin{array}{l}\text { Gypsum } \\
<2 \mathrm{~mm} \\
(\mathrm{~g} / \mathrm{kg})\end{array}$} & \multirow[t]{2}{*}{$\mathrm{SAR}^{\mathrm{b}}$} \\
\hline & & & & & & & & & $\begin{array}{l}<2 \mathrm{~mm} \\
(\mathrm{~g} / \mathrm{kg})\end{array}$ & $\begin{array}{l}2-19 \mathrm{~mm} \\
(\mathrm{~g} / \mathrm{kg})\end{array}$ & & \\
\hline A1 & $0-2$ & 33.5 & 42.3 & 24.2 & 0.135 & 10YR3/3, 2npl, so & 17.8 & 0 & 2.4 & $-^{c}$ & 0.13 & 1 \\
\hline $\mathrm{A} 2$ & $2-5$ & 36.1 & 41.2 & 22.7 & 0.132 & 10YR3/3, $1 \mathrm{npl}$, so & 15.9 & 0 & 2.4 & - & 1.40 & $\operatorname{Tr}^{c}$ \\
\hline By1 & $5-23$ & 11.3 & 64.1 & 24.6 & 0.148 & 10YR6/4, massive, so & 3.7 & 0 & 1.1 & - & 9.17 & $\operatorname{Tr}$ \\
\hline By2 & $23-30$ & 8.8 & 63.9 & 27.3 & 0.046 & 10YR7/3, massive, so & 2.2 & 0 & 2.1 & - & 7.66 & 4 \\
\hline 2Byb1 & $30-38$ & 6.2 & 73.2 & 20.6 & 0.032 & 10YR7/3, massive, so & 2.9 & 1 & 3.5 & 9.2 & 6.49 & 7 \\
\hline 2Byb2 & $38-52$ & 4.0 & 70.2 & 25.8 & 0.025 & 10YR7/3, massive, so & 3.3 & 10 & 5.4 & 9.1 & 4.34 & 11 \\
\hline 2Bkmb1 & $52-66$ & 4.2 & 28.2 & 67.6 & $\mathrm{Nd}^{\mathrm{c}}$ & $10 \mathrm{YR} 7 / 3,1 \mathrm{cpl}, \mathrm{eh}, \mathrm{ci}$ & 3.4 & 70 & 8.2 & 8.7 & 0.68 & 11 \\
\hline $2 \mathrm{Bkmb} 2$ & $66-86$ & 31.0 & 40.8 & 28.2 & $\mathrm{Nd}$ & 10YR6/3, 1cpl, eh, ci & 5.0 & 26 & 8.1 & 7.8 & 0.07 & 12 \\
\hline 2Bkb1 & $86-94$ & 25.0 & 49.5 & 25.5 & $\mathrm{Nd}$ & 7.5YR6/4, massive, h & 5.9 & 6 & 7.8 & 7.8 & 0.09 & 12 \\
\hline $2 \mathrm{Bkb} 2$ & $94-102$ & 10.6 & 69.6 & 19.8 & $\mathrm{Nd}$ & 7.5YR5 /4, massive, so & 11.6 & 1 & 5.0 & 3.7 & 0.84 & 15 \\
\hline $2 \mathrm{Bkb} 3$ & $102-117$ & 12.9 & 72.9 & 14.2 & $\mathrm{Nd}$ & 7.5YR5 /4, massive, so & 10.7 & 1 & 4.8 & - & 0.47 & 14 \\
\hline $3 \mathrm{C}$ & $117-132$ & 7.8 & 60.7 & 31.5 & $\mathrm{Nd}$ & 5YR 4/6, massive, sh & 18.1 & 2 & 1.0 & - & 2.15 & 13 \\
\hline
\end{tabular}

${ }^{\mathrm{a}}$ See Table 5 for additional abbreviations. Munsell colors are moist.

${ }^{\mathrm{b}} \mathrm{SAR}=$ sodium adsorption ratio (see Burt, 1995).

${ }^{\mathrm{c}} \mathrm{Nd}=$ not determined; $(-)=$ none detected; $\mathrm{Tr}=$ trace. 
Table 11

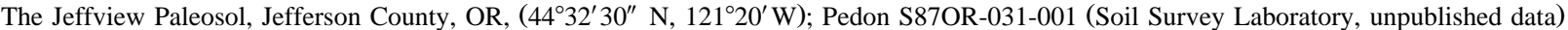

Classification: Complete, Oxidized, Unleached, Enduric Paleoaridisol, eolian/pyroclastic, extensive.

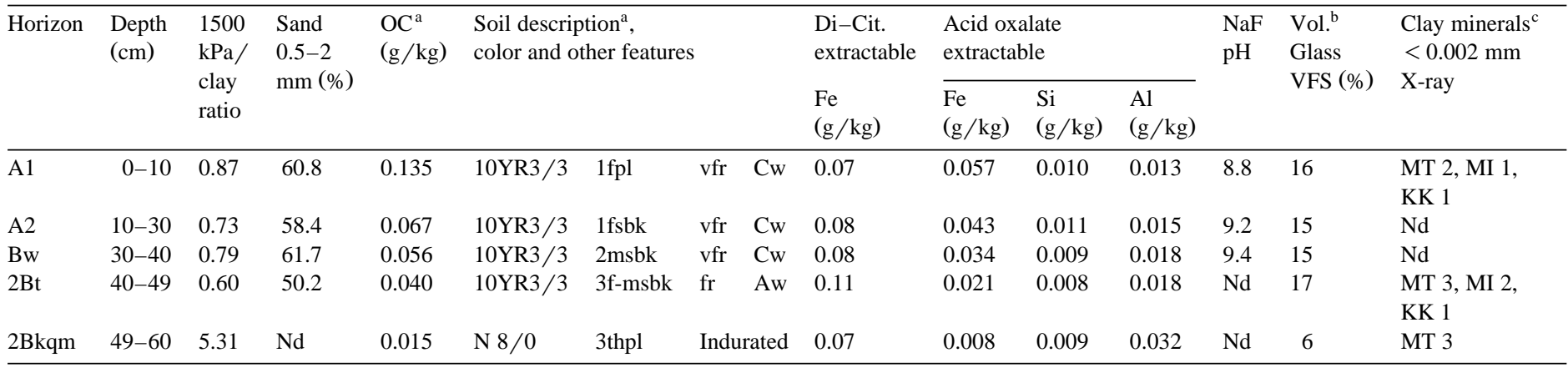

${ }^{\text {a }}$ See Tables 5 and 6 for abbreviations. Munsell color is moist.

${ }^{\mathrm{b}}$ Vol. Glass = volcanic glass including glass shards and glass-coated sands in the very fine sand (VFS) fraction $(0.10-0.05 \mathrm{~mm})$.

${ }^{\mathrm{c}} \mathrm{MT}=$ smectite; $\mathrm{MI}=$ clay mica; KK = kaolinite. Numbers refer to peak height for XRD: 3 = medium, 2 = small, $1=$ very small (see Burt, 1995). 

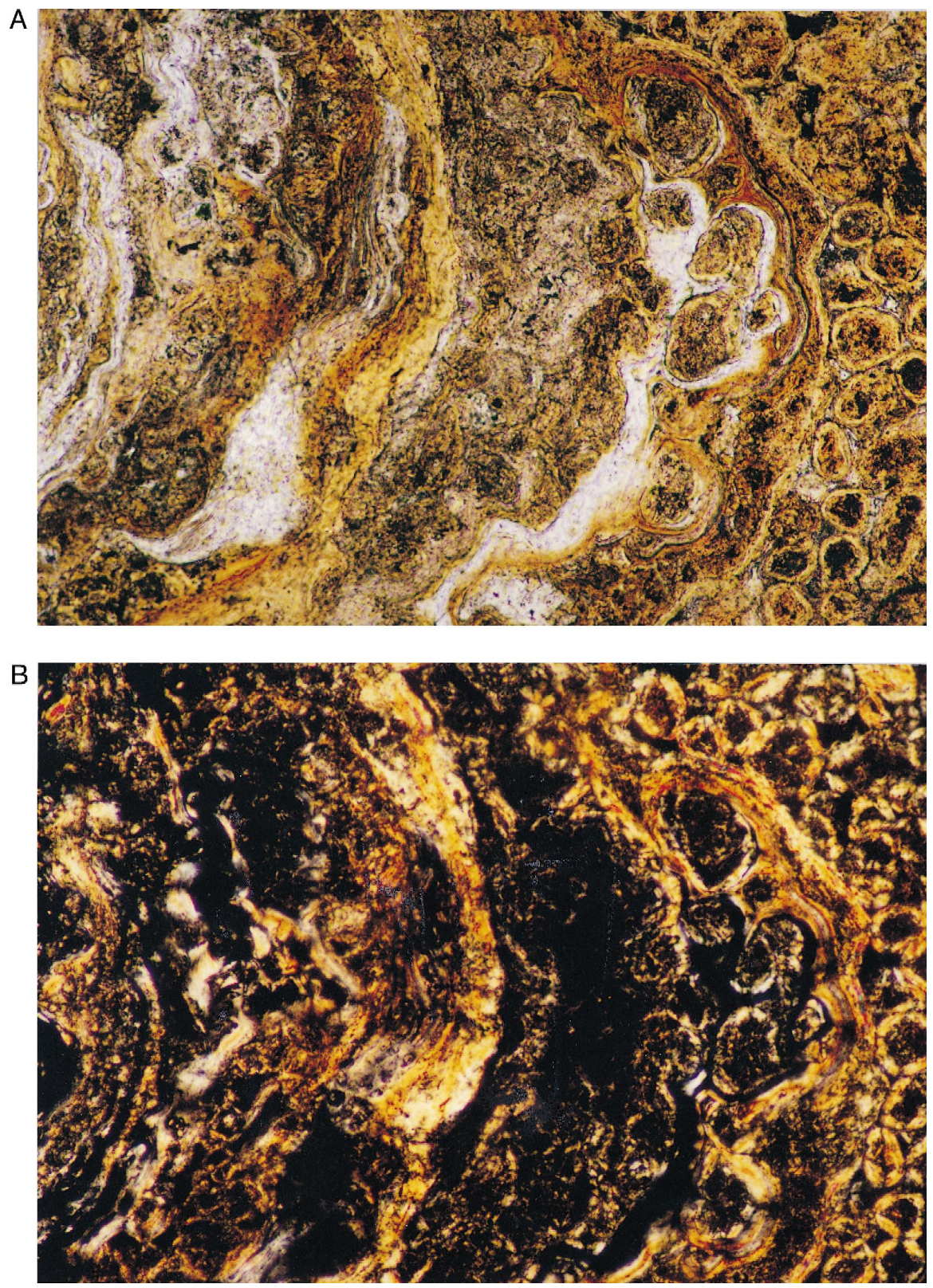

Fig. 3. Photomicrograph from the upper part of the 2Bkqm horizon of the Jeffview Paleosol. (A) In plain light showing rounded durinodes with surrounding argillans and alternating laminae of white opal and yellowish argillans. Most of the silica cement in the durinodes and matrix of the duripan are brown in color and occur as aggregates of clay size material. The white laminae are glassy. (B) In crossed polarized light showing that the argillans have sharp extinction brushes and that the silica is isotropic. Frame width $=2 \mathrm{~mm}$. 


\subsection{The Augusta Paleosol}

This paleosol occurs below an Ultisol formed in Pliocene colluvium over earlier Tertiary sediment from the inner Coastal Plain of Randolph County, GA (Table 12). Pavich et al. (1981) consider the colluvium to be $2.5 \mathrm{Ma}$ old and the Tertiary sediment no younger than early Pliocene. The Augusta Paleosol is in the Tertiary sediment and extends to a depth greater than $10 \mathrm{~m}$. It disperses easily in sodium hexametaphosphate solution (Soil Survey Staff, 1992b). Its $\mathrm{CEC}_{7} /$ clay content ratio shows that the clay is kaolinitic. The clay fraction from a paired paleosol (S80 GA-243-001) sampled in the same area contains $48-58 \%$ kaolinite and 1-6\% gibbsite by DTA determination as well as traces of chlorite and vermiculite-chlorite from X-ray diffraction analysis (Soil Survey Laboratory, Lincoln, NE, unpublished data). The Augusta paleosol has a kandic horizon. Occurrence of clay skins prevents its from being a Paleooxisol. The Augusta Paleosol is an example of a Truncated, Oxidized, Unleached, Kryptic Paleoeldisol, alluvial, extensive.

\subsection{The Pawnee Paleosol}

This paleosol (Table 13) is located on the Central Plains Experimental Range in the western part of the Pawnee National Grasslands of Weld County, CO. A ${ }^{14} \mathrm{C}$ age of $8840 \pm 80 \mathrm{BP}$ obtained from the $3 \mathrm{BAkb}$ horizon indicates it was buried in the early Holocene. The mollic epipedon of the paleosol is thicker and contains more OC than that of the ground soil above, an Ustic Haplargid. The OC and phytolith data suggest that the early Holocene climate was cooler and more moist than the present one (Blecker et al., 1997). The paleosol B horizon has the morphology expected of an argillic horizon. Soft masses of carbonate throughout the argillic horizon were deposited after the clay

Table 12

The Augusta Paleosol, Randolph County, GA (332 $\left.3^{\prime} \mathrm{N}, 81^{\circ} 59^{\prime} \mathrm{W}\right)$, Pedon S80 GA-243-002 (Soil Survey Laboratory, unpublished data)

Classification: Truncated, Oxidized, Leached, Kryptic Paleoeldisol, alluvial, extensive.

\begin{tabular}{|c|c|c|c|c|c|c|c|c|}
\hline \multirow[t]{2}{*}{ Horizon } & \multirow{2}{*}{$\begin{array}{l}\text { Lower } \\
\text { depth } \\
(\mathrm{cm})\end{array}$} & \multirow{2}{*}{$\begin{array}{l}\text { Clay } \\
<0.002 \\
\mathrm{~mm}(\%)\end{array}$} & \multirow{2}{*}{$\begin{array}{l}\mathrm{CEC}_{7} \\
\text { /clay } \\
\text { ratio }\end{array}$} & \multirow{2}{*}{$\begin{array}{l}\mathrm{OC}^{\mathrm{a}} \\
(\mathrm{g} / \mathrm{kg})\end{array}$} & \multirow{2}{*}{$\begin{array}{l}\mathrm{Fe} \\
\mathrm{DC} \\
(\mathrm{g} / \mathrm{kg})\end{array}$} & \multicolumn{3}{|c|}{ Soil description $^{\mathrm{a}}$} \\
\hline & & & & & & Color & Structure & Clay skins ${ }^{b}$ \\
\hline $\mathrm{C} 2$ & 690 & 24.1 & 0.05 & 0.003 & 0.16 & $10 Y R 5 / 6$ & Massive & - \\
\hline $2 \mathrm{Bt} 1 \mathrm{~b}$ & 738 & 16.9 & 0.05 & 0.002 & 0.10 & 5YR 5/6 & Massive & - \\
\hline $2 \mathrm{Bt} 2 \mathrm{~b}$ & 797 & 15.7 & 0.06 & 0.002 & 0.10 & 7.5YR 5/6 & Massive & - \\
\hline $2 \mathrm{Bt} 3 \mathrm{~b}$ & 828 & 20.5 & 0.06 & 0.002 & 0.16 & 7.5YR 5/6 & Massive & - \\
\hline $3 \mathrm{Bt} 4 \mathrm{~b}$ & 860 & 30.2 & 0.07 & 0.003 & 0.27 & $2.5 \mathrm{YR} 4 / 6$ & Massive & $\operatorname{lnpf}$ \\
\hline $3 \mathrm{Bt} 5 \mathrm{~b}$ & 940 & 19.3 & 0.05 & 0.002 & 0.16 & 2.5 YR $5 / 8$ & Massive & - \\
\hline $3 \mathrm{Bt} 6 \mathrm{~b}$ & 1034 & 20.9 & 0.06 & 0.002 & 0.17 & 5YR 5/6 & Massive & - \\
\hline $3 \mathrm{Bt} 7 \mathrm{~b}$ & 1070 & 33.4 & 0.04 & 0.003 & 0.17 & $5 Y R 5 / 8$ & Massive & $\operatorname{lnpf}$ \\
\hline
\end{tabular}

\footnotetext{
${ }^{\mathrm{a}}$ See Tables 5 and 6 for abbreviations. Munsell color is moist.

${ }^{\mathrm{b}} \operatorname{lnpf}=$ few thin clay skins (illuviation argillans ) on ped faces; $(-)=$ no clay skins detected.
} 
Table 13

The Pawnee Paleosol, Weld County, CO

Central Plains Experimental Range in the western part of the Pawnee National Grasslands (Blecker et al., 1997; site 1).

Classification: Accretionary, Oxidized, Leached, Kryptic Paleomollisol, alluvial, inextensive.

\begin{tabular}{lllllll}
\hline Horizon & $\begin{array}{l}\text { Depth } \\
(\mathrm{cm})\end{array}$ & $\begin{array}{l}\text { Clay } \\
(\%)\end{array}$ & $\begin{array}{l}\text { Silt } \\
(\%)\end{array}$ & $\begin{array}{l}\text { Sand } \\
(\%)\end{array}$ & $\begin{array}{l}\text { OC } \\
(\mathrm{g} / \mathrm{kg})\end{array}$ & $\begin{array}{l}\text { Soil description }^{\mathrm{a}}, \\
\text { color and other features }\end{array}$ \\
\hline 2BC & $175-197$ & 23.0 & 20.3 & 56.7 & 0.015 & 10 YR6/3, eo \\
3ABkb & $197-219$ & 41.0 & 41.5 & 17.5 & 0.075 & $10 Y \mathrm{Y} 3 / 3, \mathrm{sm}, \mathrm{spf}, 2 \mathrm{npf}$ \\
3BAkb & $219-248$ & 41.1 & 43.6 & 15.3 & $0.129^{\mathrm{b}}$ & $10 Y \mathrm{Y} 3 / 2, \mathrm{sm}, \mathrm{spf}, 2 \mathrm{npf}$ \\
3Btkb & $248-280$ & 33.8 & 35.1 & 31.1 & 0.078 & $10 Y \mathrm{Y} 4 / 2, \mathrm{sm}, \mathrm{spf}, 2 \mathrm{npf}$ \\
\hline
\end{tabular}

${ }^{\mathrm{a}}$ Munsell colors are moist. Abbreviations for carbonate accumulation are: eo = not effervescent; $\mathrm{sm}=$ carbonate as soft masses; $\mathrm{spf}=$ carbonate as prominent coatings on ped faces; abbreviations for clay skins are: $2 \mathrm{npf}=$ prominent, discontinuous clay skins (illuviation argillans) on ped faces.

${ }^{\mathrm{b}} \mathrm{A}{ }^{14} \mathrm{C}$ age from this horizon yielded $8840 \pm 80$ BP (Blecker et al., 1997).

had been translocated. The Pawnee Paleosol is an Accretionary, Oxidized, Leached, Kryptic Paleomollisol, alluvial, inextensive.

\subsection{The Vladimir Paleosol}

This paleosol (Table 14) occurs in the Vladimir Oblast on the Opolie, the Russian Plain of the Russian Republic. The paleosol is the ground soil in some hillslope positions and is buried at others. Where sampled, it is buried by $<37 \mathrm{~cm}$ of silty sediment; hence, is not a buried soil by Soil Taxonomy definitions, and as a ground soil may classify as a fine silty, frigid, Pachic Argiudoll (Soil Survey Staff, 1998). Silty sediments buried the paleosol in the Holocene. It has not lost significant amounts of OC since burial. The buried A horizon contains more OC than the cultivated ground soil, but is too thin to be mollic and the underlying horizon, although dark enough to be mollic, does not contain enough OC to qualify (Soil Survey Laboratory, Lincoln, NE, unpublished data). The weatherable mineral content of the coarse silt is in the range for either Paleomollisols or Paleoevolvisols. Smectite also dominates the clay mineral suite below the buried A horizon, showing that the environment in which the soil formed was base-rich and weathering has not been severe. The Vladimir Paleosol is an Accretionary, Oxidized, Leached, Enduric Paleoevolvisol, eolian/colluvial, extensive.

\subsection{The Rend Lake Paleosol}

This example (Table 15) formed in thin reworked Illinoian drift over interbedded fine-grained sandstone and shale in Jefferson County, IL. An Aeric Epiaqualf developed in Wisconsinan loess overlies the buried paleosol. Silt grains from the loess accumulated in channels (Fig. 4) in upper horizons of the paleosol during its burial; note the higher silt content of the upper part of the paleosol (Table 15). The paleosol has an argillic horizon, a $\mathrm{CEC}_{7} /$ clay ratio $\geq 0.4$, and $\geq 15 \%$ weatherable minerals in the very fine sand fraction $(0.10-0.05 \mathrm{~mm})$. The upper part of the paleosol has low chroma and is 
Table 14

The Vladimir Paleosol, Russian Plain, Vladimir Oblast, Russian Republic, Pedon S90FN-805-007 (Soil Survey Laboratory, unpublished data)

Classification: Accretionary, Oxidized, Leached, Enduric Paleoevolvisol, eolian/colluvial, extensive.

\begin{tabular}{|c|c|c|c|c|c|c|c|c|c|c|c|}
\hline Horizon & $\begin{array}{l}\text { Depth } \\
(\mathrm{cm})\end{array}$ & $\begin{array}{l}\text { Clay } \\
(\%)\end{array}$ & $\begin{array}{l}\text { Silt } \\
(\%)\end{array}$ & $\begin{array}{l}\text { Sand } \\
(\%)\end{array}$ & $\begin{array}{l}\mathrm{OC}^{\mathrm{a}} \\
(\mathrm{g} / \mathrm{kg})\end{array}$ & $\begin{array}{l}\text { Fe DC } \\
(\mathrm{g} / \mathrm{kg})\end{array}$ & $\begin{array}{l}\text { Soil description }{ }^{\mathrm{a}} \text {, } \\
\text { color and other features }\end{array}$ & $\begin{array}{l}\mathrm{CEC}_{7} / \\
\text { clay ratio }\end{array}$ & $\begin{array}{l}\text { Weatherable } \\
\text { minerals }(\%)\end{array}$ & $\begin{array}{l}\mathrm{BS}_{8.2} \\
(\%)\end{array}$ & $\begin{array}{l}\text { Clay minerals }{ }^{\mathrm{b}} \\
<0.002 \mathrm{~mm} \text { XRD }\end{array}$ \\
\hline $\mathrm{Ab}$ & $37-53$ & 19.4 & 77.4 & 3.2 & 0.319 & 0.09 & 7.5YR $2 / 0,1 \mathrm{msbk}-$ & 1.36 & 34 & 56 & KK 2, VR 2, MI 2, MM 1 \\
\hline $\mathrm{BAb}$ & $53-58$ & 16.0 & 80.0 & 4.0 & 0.047 & 0.08 & $5 Y R 3 / 3,2$ fabk & 0.71 & $\mathrm{Nd}$ & 58 & $\mathrm{Nd}$ \\
\hline $\mathrm{Bt} / \mathrm{Eb} 1$ & $58-90$ & 28.0 & 66.9 & 5.1 & 0.027 & 0.12 & 7.5YR 5/6, 1m-cpr, 1p & 0.62 & 41 & 58 & MT 4, MI 3, KK 3, MM 2 \\
\hline $\mathrm{Bt} / \mathrm{Eb} 2$ & $90-137$ & 34.0 & 63.3 & 2.7 & 0.025 & 0.15 & 7.5YR4/4, 1m-cpr, $1 \mathrm{cp}$ & 0.65 & $\mathrm{Nd}$ & 65 & $\mathrm{Nd}$ \\
\hline Btb & $137-180$ & 34.9 & 62.1 & 3.0 & 0.020 & 0.13 & 10 YR 5/6, 1m-pr & 0.69 & $\mathrm{Nd}$ & 79 & MT 4, MI 3, KK 3, MM 2 \\
\hline $\mathrm{BCb}$ & $180-200$ & 33.8 & 63.5 & 2.7 & 0.020 & 0.13 & 10YR 6/6, 1cabk & 0.75 & $\mathrm{Nd}$ & 90 & MT 3, MI 3, KK 3, MM 2 \\
\hline
\end{tabular}

${ }^{\mathrm{a}}$ See Tables 5 and 6 and Soil Survey Staff (1951) for abbreviations.

${ }^{\mathrm{b}}$ Clay minerals are: $\mathrm{KK}=$ kaolinite; $\mathrm{VR}=$ vermiculite; $\mathrm{MI}=$ clay mica; $\mathrm{MM}=$ smectite; numbers refer to peak height for $\mathrm{XRD}$ : $4=$ large; $3=$ medium; $2=$ small; 1 = very small (see Burt, 1995). 
Table 15

The Rend Lake Paleosol

The Mt. Vernon State Game Farm Headquarters, about 3 km south of Mt. Vernon, Jefferson County, IL, (SW 1/4 NE 1/4 Sec. 28, T. 35S., R. 3E.). Pedon S90Il-81-001 (Soil Survey Laboratory, unpublished data). Thin sections were prepared for only the 3Btgb1, 4BCrb, and R horizons.

Classification: Accretionary, Gleyed, Leached, Kryptic Paleovolvisol, colluvial, inextensive.

\begin{tabular}{|c|c|c|c|c|c|c|c|c|c|c|c|}
\hline Horizon & $\begin{array}{l}\text { Depth } \\
(\mathrm{cm})\end{array}$ & $\begin{array}{l}\text { Clay } \\
(\%)\end{array}$ & $\begin{array}{l}\text { Silt } \\
(\%)\end{array}$ & $\begin{array}{l}\text { Sand } \\
(\%)\end{array}$ & $\begin{array}{l}\mathrm{OC}^{\mathrm{a}} \\
(\mathrm{g} / \mathrm{kg})\end{array}$ & $\begin{array}{l}\mathrm{Fe} \\
(\mathrm{g} / \mathrm{kg})\end{array}$ & $\begin{array}{l}\text { Soil description }{ }^{\mathrm{a}} \text {, } \\
\text { color and other features }\end{array}$ & $\begin{array}{l}\mathrm{CEC}_{7} / \\
\text { clay ratio }\end{array}$ & $\begin{array}{l}\text { Weatherable } \\
\text { minerals }(\%)\end{array}$ & $\begin{array}{l}\mathrm{BS}_{8.2} \\
(\%)\end{array}$ & $\begin{array}{l}\text { Clay minerals } \\
<0.002 \mathrm{~mm} \mathrm{XRD}^{\mathrm{b}}\end{array}$ \\
\hline $2 \mathrm{Btgb} 1$ & $63-75$ & 25.7 & 70.2 & 4.1 & 0.011 & 0.15 & 10YR 5/2, 2cpr, $1 \mathrm{npf}$ & 0.50 & 39 & 42 & MT4, KK3, MM2, VR2, MI2 \\
\hline $2 \mathrm{Btgb} 2$ & $75-94$ & 22.0 & 64.7 & 13.3 & 0.012 & 0.16 & $10 \mathrm{YR} 5 / 2,1 \mathrm{cpr}, 1 \mathrm{npf}$ & 0.48 & 18 & 53 & $\mathrm{Nd}$ \\
\hline $2 \mathrm{Btg} x \mathrm{~b} 1$ & $94-125$ & 21.7 & 57.6 & 20.7 & 0.009 & 0.12 & $10 \mathrm{YR} 5 / 2$ and $5 / 6,1 \mathrm{cpr}, 1 \mathrm{npf}$ & 0.47 & 18 & 57 & MT4, VR2, MM2, MI1 \\
\hline 2Btgxb2 & $125-155$ & 22.3 & 50.1 & 27.6 & 0.008 & 0.10 & $10 \mathrm{YR} 5 / 2$ and $5 / 6,1 \mathrm{cpr}, 1 \mathrm{npf}$ & 0.43 & 14 & 78 & $\mathrm{Nd}$ \\
\hline $3 B \operatorname{tg} x b 3$ & $155-180$ & 23.2 & 47.6 & 29.2 & 0.008 & 0.08 & 10YR 5/2, 1cpr, $1 \mathrm{npf}$ & 0.43 & 15 & 84 & MT4, VR2, MM2, MI1 \\
\hline $3 \mathrm{ABtgb}$ & $180-215$ & 20.5 & 45.3 & 34.2 & 0.008 & 0.07 & 10YR 5/2, 1cpr, 1npf & 0.48 & 13 & 81 & $\mathrm{Nd}$ \\
\hline 3Btgb1 & $215-235$ & 26.6 & 41.9 & 31.5 & 0.008 & 0.24 & 7.5YR 5/8, 2mabk, $1 \mathrm{npf}$ & 0.47 & 17 & 81 & MT3, KK3, VR3, MM2, GE2 \\
\hline $3 \mathrm{Btgb} 2$ & $235-260$ & 30.9 & 31.6 & 37.5 & 0.010 & 0.27 & 10YR 4/6, 1msbk, 1npf & 0.47 & 19 & 83 & $\mathrm{Nd}$ \\
\hline 4BCtrb & $260-280$ & 25.6 & 25.7 & 48.7 & 0.009 & 0.31 & 10YR 4/6, massive, $4 \mathrm{kpo}$ & 0.51 & 29 & 87 & $\mathrm{Nd}$ \\
\hline $4 \mathrm{Rb}^{\mathrm{c}}$ & $280-300$ & 9.6 & 18.9 & 71.5 & 0.005 & 0.21 & $10 \mathrm{YR} 5 / 6$, ss and $\mathrm{sh}^{\mathrm{c}}$ & 0.68 & $\mathrm{Nd}$ & 85 & $\mathrm{Nd}$ \\
\hline
\end{tabular}

${ }^{\mathrm{a}}$ See Tables 5 and 6 for abbreviations. Munsell colors are moist.

${ }^{\mathrm{b}} \mathrm{MT}=$ smectite; $\mathrm{KK}=$ kaolinite; $\mathrm{MM}=$ montmorillonite; $\mathrm{VR}=$ vermiculite; $\mathrm{MI}=$ clay-size mica; GE = goethite. Numbers refer to peak height for XRD only $5=$ very large; $4=$ large; $3=$ medium; 2 = small; 1 = very small (see Burt, 1995).

${ }^{\mathrm{c}}$ Rock is fine-grained sandstone and shale. 


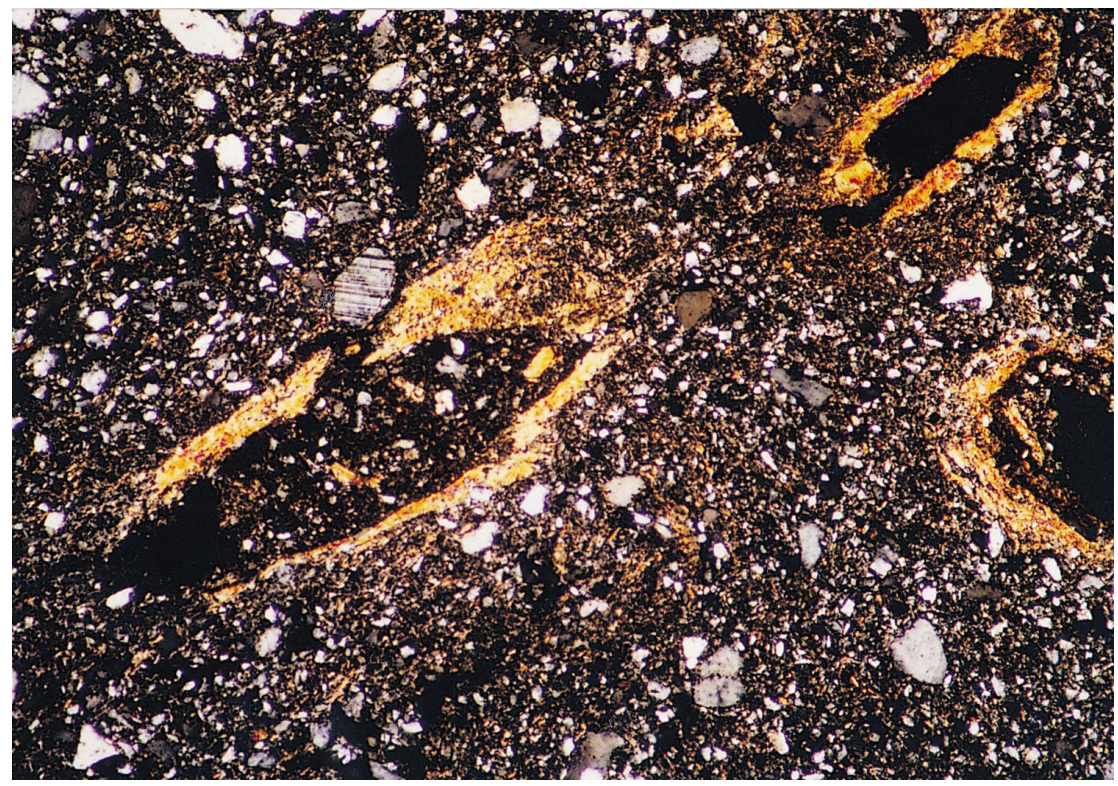

Fig. 4. Photomicrograph from the $2 \mathrm{Btgxb} 1$ horizon of the Rend Lake Paleosol in crossed polarized light showing silt in channels bordered by illuviation argillans. Frame width $=2 \mathrm{~mm}$.

mottled, showing that it is gleyed. In this area, the upper part of the paleosol commonly has alternating thin laminar bands of light and dark silt loam sediment. The material above the sandstone shale residuum is 1-2 m thick, occasionally stratified, and contains sub-rounded pebbles typical of water transport. In some areas, the material has the compactness and angular pebbles more typical of till. We believe that the material is either pedisediment or outwash. Because the paleosol may have been resaturated with bases following loess burial, we ignore the $\mathrm{BS}_{8.2}$ values in classifying this paleosol as an Accretionary, Gleyed, Leached, Kryptic Paleoevolvisol, colluvial, inextensive.

\subsection{The Naron Paleosol}

Occurring in Edwards County, KS (Table 16), this is similar to a Paleovertisol (Table 1). It has a linear extensibility $>5 \%$, a masepic plasmic fabric, a clay fraction dominated by smectite and a clay content $>30 \%$. However, there are no slickensides or wedge-shaped aggregates. The plasmic fabric is evidence for a cambic horizon. Based on a ${ }^{14} \mathrm{C}$ age of $7100 \mathrm{BP}$ in the $2 \mathrm{Ab}$, the eolian sands derived from the Arkansas River and overlying the paleosol are Holocene. An Argiustoll has formed in the eolian sands. Feng et al. (1994) suggested that the early Holocene was an optimal time for soil development and was followed by a dry period of eolian sand accumulation in central Kansas. The minor carbonate accumulations may have occurred during the drier mid-Holocene. The $2 \mathrm{Ab}$ horizon of the paleosol has the dark epipedon colors but is too 
Table 16

The Naron Paleosol, Edwards County, KS (37 59 $37^{\prime \prime} \mathrm{N}$ and $\left.98^{\circ} 56^{\prime} 55^{\prime \prime} \mathrm{W}\right)$, Pedon S87KS-47-002 (Soil Survey Laboratory, unpublished data)

Classification: Accretionary, Gleyed, Leached, Kryptic Paleoinceptisol, alluvial, extensive.

\begin{tabular}{|c|c|c|c|c|c|c|c|c|c|c|c|}
\hline Horizon & $\begin{array}{l}\text { Depth } \\
(\mathrm{cm})\end{array}$ & $\begin{array}{l}\text { Clay } \\
(\%)\end{array}$ & $\begin{array}{l}\text { Silt } \\
(\%)\end{array}$ & $\begin{array}{l}\text { Sand } \\
(\%)\end{array}$ & $\begin{array}{l}\mathrm{OC}^{\mathrm{a}} \\
(\mathrm{g} / \mathrm{kg})\end{array}$ & $\begin{array}{l}\text { Soil description }{ }^{\mathrm{a}} \text {, } \\
\text { color and other features }\end{array}$ & LE $(\%)$ & $\begin{array}{l}\mathrm{CEC}_{7} / \\
\text { clay ratio }\end{array}$ & $\begin{array}{l}\mathrm{CO}_{3} \text { as } \\
\mathrm{CaCO}_{3}\end{array}$ & $\begin{array}{l}\mathrm{K}_{2} \mathrm{O} \\
(\mathrm{g} / \mathrm{kg})\end{array}$ & $\begin{array}{l}\text { Clay minerals } \\
(<0.002 \mathrm{~mm}) \mathrm{XRD}\end{array}$ \\
\hline $\mathrm{C}$ & $136-146$ & 16.4 & 16.7 & 66.9 & 0.019 & 10YR4/4, massive, eo & $\mathrm{Nd}$ & 0.88 & $\operatorname{Tr}$ & $\mathrm{Nd}$ & \\
\hline $2 \mathrm{Ab}$ & $146-161$ & 40.8 & 50.6 & 8.6 & $0.042^{b}$ & $10 \mathrm{YR} 3 / 1,2 \mathrm{mabk}$, eo & 7.1 & 0.80 & 0.1 & 0.20 & MT 4, MI 3, KK 3 \\
\hline 2Bkb1 & $161-180$ & 36.8 & 58.9 & 4.3 & 0.023 & $10 \mathrm{YR} 5 / 2,2 \mathrm{mpr}$, es, sm & $\mathrm{Nd}$ & 0.86 & 0.2 & $\mathrm{Nd}$ & \\
\hline $2 \mathrm{Bkb} 2$ & $180-206$ & 33.1 & 62.5 & 4.4 & 0.015 & $5 \mathrm{Y} 6 / 2,2 \mathrm{mpr}, \mathrm{es}, \mathrm{spf}$ & $\mathrm{Nd}$ & 0.95 & 0.2 & $\mathrm{Nd}$ & \\
\hline $2 \mathrm{BCb}$ & $206-225$ & 29.9 & 64.7 & 5.4 & 0.010 & $5 \mathrm{Y} 6 / 2,1 \mathrm{mpr}$, es & 5.2 & 0.94 & 0.1 & 0.17 & MT 4, MI 3, KK 3 \\
\hline
\end{tabular}

${ }^{a}$ See Tables 5 and 6 and Soil Survey Staff (1951) for additional abbreviations. Munsell color is moist. Carbonate codes as in Table 13. The prismatic structure of the $2 \mathrm{BCb}$ horizon parts to weak medium subangular. All others part to moderate to strong medium angular blocky.

${ }^{\mathrm{b}} \mathrm{A}{ }^{14} \mathrm{C}$ age for this horizon is 7100 years BP. Wood obtained below the paleosol was dated at 23,000 years BP. 
thin and lacks the necessary OC content $(>0.6 \%)$ to be mollic, so it classifies as an Accretionary, Gleyed, Leached, Kryptic Paleoinceptisol, alluvial, inextensive.

\section{Discussion and conclusions}

Experience has shown that paleosols like those described above can be classified in a property-based system such as that proposed at the 1993 Paleopedology Symposium (Nettleton et al., 1998). Because of the complexity observed in paleosols, we have chosen to define only 11 orders. This parallels the number and, in general, the kinds of soil orders that were included in the Keys to Soil Taxonomy between 1990 and 1996 (Soil Survey Staff, 1990, 1992a, 1996). When the intent of the classification system is to place paleosols with similar environments of formation together, both diagenetically altered and unaltered paleosols should be included in the same classes. The complexity of paleosols also argues against expanding the number of orders because present investigative techniques are inadequate for more detailed differentiation of paleosols.

By design, the classes of the revised system relate to paleoenvironments. Interpretation of past environments is an important objective of global climate change initiatives. This classification system facilitates that objective. Interpretation of past environments for paleosols is done by comparison to present-day soils where Holocene climate can be measured.

Many properties of paleosols on Holocene surfaces are in equilibrium with the environment. OC, base saturation, $\mathrm{pH}$, salt, and carbonate profiles adjust to an environment within a few thousand years or less. Even argillic and natric horizons are known to develop in a few thousand years. Many properties of relict and exhumed paleosols are also adjusted to, or modified by, the present environment. Thus, in part, their environments of formation can be understood. However, their more lasting properties such as clay mineralogy, silt and sand mineralogy, amounts of major elements in salt- and carbonate-free fractions, and soil microfabrics, better reflect their past environment or environments.

The longer a paleosol and its surface exist, the more difficult it is to make an interpretation about its initial climate because climate changes with time. Relict paleosols, by definition, have persisted through one or more climatic cycles that differ from the present. The dilemma occurs in matching morphological features to cycles. Has one of the cycles had a dominant influence on paleosol development? Did the inherited features that we see and describe originate in the dominant cycle or a combination of all cycles? A duripan is an extreme example, as it is a dominant feature of a relict paleosol; is it a product of a single dry period sandwiched between humid episodes of long duration (thousands of years) that left little morphological imprint, or is it a feature of the most dominant soil-forming period?

Exhumation exposes both a buried paleosol and parts of the former land surface. An exhumed profile is rarely intact. Commonly, the A horizon is truncated, is a mixed sediment, or is completely stripped and the B horizon is the best-preserved recognizable feature. Exposure time and the rate of climate change determine the number of climate cycles that an exhumed paleosol is subject to. Interpretation difficulties are similar to 
those encountered for relict paleosols. However, for most exhumed paleosols, we have the advantage of observing the buried equivalent to assist in separating initial paleoenvironmental features from those developed after exhumation. We must consider potential diagenesis in both the exhumed and buried equivalents.

Buried paleosols are less likely to be influenced by the present climate because their development is largely arrested by burial. Schaetzl and Sorenson (1987) suggest that there are minimum burial depths below which soil properties become isolated from subaerial effects. With the exception of welding (Ruhe and Olson, 1980), buried paleosols are often related to one primary climate cycle. Post-burial changes and alteration such as oxidation and loss of organic matter still occur (Olson and Nettleton et al., 1998). Drainage of the paleosol may have changed, even for lithified paleosols (Joeckel, 1991). The gleyed B horizon of the Eskridge Paleosol above a petrocalcic horizon is an example of post-burial drainage changes. The challenge for interpreting paleoenvironments of buried paleosols is determining which features are diagenetic and which are pedogenic.

Given that the environmental history of many paleosols is complex, how do we make scientifically credible interpretations? We suggest that paleosols are best studied in traverses that include toposequence changes, i.e. various kinds of paleosols and ground soils across a landscape. Ideally, buried paleosols should be studied below the influence of welding processes. Compare exhumed paleosols with buried equivalents and relict paleosols to other ground soils. Where possible, consider the length of time each ground soil and paleosol has been exposed to soil-forming processes. Consider the nature of the parent materials and the overlying materials. Test conclusions against another traverse in a similar landscape, and against a regional or broader climatic pattern. If results are consistent, confidence in the conclusions will increase with each step in the empirical procedure.

Paleosol orders provide the first level for paleoenvironmental interpretation. This agrees with the statement by Buurman (1993) that "paleosols cannot be classified in as much detail as modern soils, at least if the link with paleoenvironment is to be preserved, and that there will usually remain some doubt as to the correct name.' In this context, the environmental interpretation of paleosols may be as well supported by the modifiers of the orders as by the orders themselves. Modifiers are site-specific and are derived from a detailed knowledge of the site including the paleolandscape. Modifiers may be the key to further refinement of paleosol classifications.

\section{References}

Alexander, L.T., Cady, J.G., 1962. Genesis and hardening of laterite in soils. U.S. Department of Agriculture Technical Bulletin 1282. United States Government Printing Office, Washington, DC, 90 pp.

Baker, R.G., 1983. Holocene vegetational history of the western US. In: Wright, H.E. Jr. (Ed.), The Holocene-Late Quaternary Environments of the US. University of Minnesota Press, Minneapolis, MN, pp. $109-127$.

Barshad, I., 1955. Soil development. In: Bear, F.E. (Ed.), Chemistry of the Soil. Van Nostrand-Reinhold, New York, pp. 1-52. 
Blecker, S.W., Yonker, C.M., Olson, C.G., Kelly, E.F., 1997. Paleopedologic and geomorphic evidence for Holocene climate variation, short grass steppe, Colorado, USA. Geoderma 76, 113-130.

Blokhuis, W.W., 1993. Vertisols in the Central Clay Plain of the Sudan. Agricultural University, Wageningen, the Netherlands, 418 pp.

Brewer, R., 1976. Fabric and Mineral Analysis of Soils. Krieger Publishing, Huntington, NY.

Bronger, A., Catt, J.A., 1989. Paleosols: Problems of definition, recognition, and interpretation. In: Bronger, A., Catt, J.A. (Eds.), Nature and Application of Paleosols. Catena Supplement Vol. 16 pp. 1-7.

Burt, R., 1995. Soil survey laboratory information manual. Soil Survey Investigations Report 45, Version 1.0, U.S. Department of Agriculture, Natural Resources Conservation Service. U.S. Government Printing Office, Washington, DC, $305 \mathrm{pp}$.

Busacca, A.J., Nelstead, K.T., McDonald, E.V., Purser, M.D., 1992. Correlation of distal tephra layers in loess in the Channeled Scabland and Palouse of Washington State. Quaternary Research 37, 281-303.

Buurman, P., 1993. Classification of paleosols - a comment. INQUA/ISSS Paleopedology Commission Newsletter 9, 3-7.

Chadwick, O.A., Olson, C.G., Hendricks, D.M., Kelly, E.F., 1994. Quantifying climatic effects on mineral weathering and neoformation in Hawaii. Transactions of the 15th World Congress of Soil Science, Acapulco, Mexico 8a, 94-105.

Davis, M.B., 1983. Holocene vegetational history of the eastern US. In: Wright, H.E. Jr. (Ed.), The Holocene-Late Quaternary Environments of the US. University of Minnesota Press, Minneapolis, MN, pp. $166-187$.

Johnson, W.C., Sprowl, D.R., Lu, Y., 1994. Loess accumulation and soil formation in central Kansas, United States, during the last 400,000 years. Earth Surface Processes and Landforms 18, 55-67.

Fenton, T.E., 1983. Mollisols. In: Wilding, L.P., Smeck, N.E., Hall, G.F. (Eds.), Pedogenesis and Soil Taxonomy: II. The Soil Orders. Elsevier, New York, pp. 125-163.

Flach, K.W., Cady, J.G., Nettleton, W.D., 1968. Pedogenic alteration of highly weathered parent materials. Transactions of the 9th International Congress of Soil Science, Adelaide 4, 343-351.

Flach, K.W., Nettleton, W.D., Chadwick, O.A., 1992. The criteria of duripans in the U.S. Soil Taxonomy and the contribution of micromorphology to characterize silica-indurated soils. Perista Terra 10, 34-45.

Flexner, S.B. (Ed.), The Random House Dictionary of the English Language. Unabridged 2nd edn. Random House Publishers, New York.

Foss, J.E., Moormann, F.R., Rieger, S., 1983. Inceptisols. In: Wilding, L.P., Smeck, N.E., Hall, G.F. (Eds.), Pedogenesis and Soil Taxonomy: II. The Soil Orders. Elsevier, New York, pp. 355-381.

Gavenda, R.T., 1992. Hawaiian Quaternary paleoenvironments: A review of geological, pedological, and botanical evidence. Pacific Science 46, 295-307.

Grossman, R.B., 1983. Entisols. In: Wilding, L.P., Smeck, N.E., Hall, G.F. (Eds.), Pedogenesis and Soil Taxonomy: II. The Soil Orders. Elsevier, New York, pp. 55-90.

Hallsworth, E.G., 1968. The gilgai phenomenon. In: Stace, H.C.T. (Ed.), A Handbook of Australian Soils. Rellim, Glenside, South Australia, pp. 415-420.

Isbell, R.F. et al., 1996. The Australian soil classification. In: Australian Soil and Land Survey Handbooks Vol. 4 CSIRO, Australia, 143 pp.

Jackson, E.A., 1957. Soil features in arid regions with particular reference to Australia. Journal of the Australian Institute of Agricultural Science 25, 196-208.

Jackson, J.A., 1997. Glossary of Geology. 4th edn. American Geological Institute, Alexandria, VA, 769 pp.

Joeckel, R.M., 1991. Paleosol stratigraphy of the Eskridge formation; Early Permian pedogenesis and climate in southeastern Nebraska. Journal of Sedimentary Petrography 61, 234-255.

Mack, G.H., James, W.C., Monger, H.C., 1993. Classification of paleosols. Geological Society of America Bulletin 105, 129-136.

McKeague, J.A., DeConinck, F., Franzmeier, D.P., 1983. Spodosols. In: Wilding, L.P., Smeck, N.E., Hall, G.F. (Eds.), Pedogenesis and Soil Taxonomy: II. The Soil Orders. Elsevier, New York, pp. 217-252.

Mermut, A.R., Sehgal, J.L., Stoops, G., 1988. Micromorphology of swell-shrink soils. In: Transactions International Workshop Swell-Shrink Soils, Classification, Management and Use Potential of Swell-Shrink Soils. Oxford \& IBH Publishing, New Delhi, India, pp. 127-144.

Miller, B.J., 1983. Ultisols. In: Wilding, L.P., Smeck, N.E., Hall, G.F. (Eds.), Pedogenesis and Soil Taxonomy: II. The Soil Orders. Elsevier, New York, pp. 283-323. 
Nettleton, W.D., Brasher, B.R., Benham, E.C., Ahrens, R.J., 1998. A classification system for buried paleosols. Quaternary International 51/52, 175-183.

Nettleton, W.D., Eswaran, H., Holzhey, C.S., Nelson, R.E., 1987. Micromorphological evidence of clay translocation in poorly dispersible soils. Geoderma 40, 37-48.

Nettleton, W.D., Flach, K.W., Brasher, B.R., 1969. Argillic horizons without clay skins. Soil Science Society of America Journal 33, 121-125.

Nettleton, W.D., Gamble, E.E., Allen, B.L., Borst, G., Peterson, F.F., 1989. Relict soils of subtropical regions of the United States. In: Bronger, A., Catt, J.A. (Eds.), Paleopedology, Nature and Applications of Paleosols. Catena Supplement Vol. 16 pp. 59-93.

Nettleton, W.D., Grossman, R.B., Brasher, B.R., 1990. Concept of argillic horizons in Aridisols. In: Kimble, J.M., Nettleton, W.D. (Eds.), Taxonomic implications. Proceedings of the Fourth International Soil Correlation Meeting (ISCOM IV) Characterization, Classification, and Utilization of Aridisols. Part A: Papers. USDA, Soil Conservation Service, Lincoln, NE, pp. 167-176.

Nettleton, W.D., Nelson, R.E., Brasher, B.R., Derr, P.S., 1982. Gypsiferous soils in the western United States. In: Kittrick, J.A., Fanning, D.S., Hossner, L.R. (Eds.), Acid Sulfate Weathering, Special Publication 19 Soil Science Society of America, Madison, WI, pp. 147-168.

Nettleton, W.D., Peterson, F.F., 1983. Aridisols. In: Wilding, L.P., Smeck, N.E., Hall, G.F. (Eds.), Pedogenesis and Soil Taxonomy: II. The Soil Orders. Elsevier, New York, pp. 165-215.

Nettleton, W.D., Sleeman, J.R., 1985. Micromorphology of Vertisols. In: Douglas, L.A., Thompson, M.L. (Eds.), Soil Micromorphology and Soil Classification Soil Science Society of America, Madison, WI, pp. 165-197, Special Publication 15.

Nikiforoff, C.C., 1937. General trends of the desert type of soil formation. Soil Science 43, 105-132.

Olson, C.G., Nettleton, W.D., 1998. Paleosols and the effects of alteration. Quaternary International 51/52, $185-194$.

Pavich, M.J., Newell, W.L., Mausbach, M.J., Paulk, H., 1981. Geomorphology and soils of the Inner Coastal plain margin near Augusta, GA: a guidebook for the Soil Science Society of America Meeting. Soil Science Society of America, Madison, WI, $61 \mathrm{pp}$.

Retallack, G.J., German-Heins, J., 1995. Evidence from paleosols for the geological antiquity of rain forest. Science 265, 499-502.

Rourke, R.V., Brasher, B.R., Yeck, R.D., Miller, F.T., 1988. Characteristic morphology of U.S. Spodosols. Soil Science Society of America Journal 52, 445-449.

Ruhe, R.V., 1964. An estimate on paleoclimate in Oahu, Hawaii. American Journal of Science 262, $1098-1115$.

Ruhe, R.V., 1965. Quaternary paleopedology. In: Wright, H.E., Frey, D.G. (Eds.), The Quaternary of the United States. Princeton University Press, Princeton, NJ, pp. 755-764.

Ruhe, R.V., 1975. Geomorphology, Geomorphic Processes and Surficial Geology. Houghton Mifflin, Boston, MA.

Ruhe, R.V., Olson, C.G., 1980. Soil welding. Soil Science 130, 132-139.

Ruhe, R.V., Williams, J.M., Shuman, R.C., Hill, E.I., 1965. Nature of soil parent materials in Ewa-Waipahu area, Oahu, Hawaii. Soil Science Society of America Proceedings 29, 282-287.

Rust, R.H., 1983. Alfisols. In: Wilding, L.P., Smeck, N.E., Hall, G.F. (Eds.), Pedogenesis and Soil Taxonomy: II. The Soil Orders. Elsevier, New York, pp. 253-281.

Schaetzl, R.J., Sorenson, C.J., 1987. The concept of 'buried' versus 'isolated' paleosols: Examples from northeastern Kansas. Soil Science 143, 426-435.

Soil Survey Staff, 1951. In: Soil Survey Manual. U.S. Department of Agriculture Handbook 18, United States Government Printing Office, Washington, DC.

Soil Survey Staff, 1975. Soil Taxonomy: A basic system of soil classification for making and interpreting soil surveys, United States Department of Agriculture, Soil Conservation Service Agricultural Handbook. U.S. Government Printing Office, Washington, DC, 436 pp.

Soil Survey Staff, 1976. Soil Survey Laboratory Data and Descriptions for Soils of Hawaii. U.S. Government Printing Office, Washington, DC.

Soil Survey Staff, 1990. Soil Series of the United States, Including Puerto Rico and the Virgin Islands, Their Taxonomic Classification. U.S. Government Printing Office, Washington, DC. 
Soil Survey Staff, 1992a. 5th edn. Keys to Soil Taxonomy. Soil Management Support Services, Technical Monograph Vol. 19 Pocahontas Press, Blacksburg, VA.

Soil Survey Staff, 1992b. Soil survey laboratory methods manual. Soil Survey Investigations Report 42, Version 2.0, U.S. Department of Agriculture, Soil Conservation Service, National Soil Survey Center, Lincoln, NE, $400 \mathrm{pp}$.

Soil Survey Staff, 1996. Keys to Soil Taxonomy. 7th edn. U.S. Department of Agriculture, Natural Resources Conservation Service, U.S. Government Printing Office, Washington, DC.

Soil Survey Staff, 1998. Keys to Soil Taxonomy. 8th edn. U.S. Department of Agriculture, Natural Resources Conservation Service, U.S. Government Printing Office, Washington, DC.

Spaargaren, O.C. (Ed.), World Reference Base for Soil Resources. ISSS, ISRIC and FAO, Wageningen.

Springer, M.E., 1958. Desert pavement and vesicular layer of some soils of the desert of the Lahontan Basin, Nevada. Soil Science Society of America Journal 22, 63-66.

Van Wambeke, A., Eswaran, H., Herbillon, A.J., Comerma, J., 1983. Oxisols. In: Wilding, L.P., Smeck, N.E., Hall, G.H. (Eds.), Pedogenesis and Soil Taxonomy: II. The Soil Orders. Elsevier, New York, pp. 325-354.

Ward, W.T., Little, I.P., Thompson, C.H., 1979. Stratigraphy of two sandrocks at Rainbow Beach, Queensland, Australia, and a note on humate composition. Paleogeography, Paleoclimatology, Paleoecology 26, 305-316.

Watts, W.A., 1983. Vegetational history of eastern US 25,000 to 10,000 years ago. In: Porter, S.C. (Ed.), The Late Pleistocene-Late Quaternary Environments of the US. University of Minnesota Press, Minneapolis, MN, pp. 294-310.

Williams, D., Touchet, B.A., 1988. Macrostructure and the bowl concept in Vertisols. Transactions International Workshop Swell-Shrink Soils. Classification, Management and Use Potential of Swell-Shrink Soils. Oxford \& IBH Publishing, New Delhi, India, pp. 41-44. 